\title{
ORALITURA Y ORATURA PALENQUERA: ENTRE ÁFRICA, EUROPA Y EL CARIBE
}

\author{
POR \\ Graciela Maglia \\ Pontificia Universidad Javeriana, Bogotá \\ Yves MoÑIno \\ Centre National de la Recherche Scientifique (CNRS), Paris
}

\section{San Basilio de Palenque, Colombia}

Los estudios sobre la lengua y la cultura afrocriolla de San Basilio de Palenque han crecido de manera fluctuante desde el "descubrimiento" de la aldea al pie de los Montes de María a mediados del siglo pasado. ${ }^{1}$ Desde entonces, la investigación científica ha realizado importantes avances, como la categorización del palenquero como lengua y no como dialecto o "deformación" local del español estándar² así como sucesivos y ricos diagnósticos sobre el futuro de la lengua (Moñino, "Pasado"). Por otra parte, la comunidad ha sido proclamada "Obra Maestra del Patrimonio Oral e Inmaterial de la Humanidad" por la UNESCO en el 2005, hecho que revierte su historia previa de discriminación y aislamiento. En este momento de superposición de valoraciones ambivalentes y de proyección mundial de la aldea local, cuando la circulación de discursos desde y sobre Palenque surcan los medios masivos, más que nunca se necesita establecer una relación complementaria entre la primordial instancia descriptiva y denotativa de los estudios etnolingüísticos e históricos y el ulterior análisis interpretativo de las prácticas discursivas palenqueras en términos de su significado literario.

Con esta finalidad, nuestra investigación parte de la difícil tarea de trasladar la expresión oral a la escritura: la triple operación de codificación oral, recodificación

1 Véase Escalante, Granda, Bickerton y Escalante, Friedemann y Patiño Rosselli, Megenney, Schwegler ("Chi ma nkongo"; "Palenquero"; "El vocabulario"; "State"), Schwegler y Morton, Moñino ("El sistema"; "Las construcciones"; "Lengua e identidad"; "Convergencias lingüísticas"; "Pasado"), Moñino y Schwegler, Lipski, entre otros.

2 Al respecto comenta Schwegler: "Las investigaciones sobre los orígenes africanos del palenquero (en adelante PAL) comenzaron en la década de los setenta y especialmente en los años ochenta, después de que Bickerton \& Escalante (1970) y Granda (1968) identificaran la lengua (denominación local del PAL) como un criollo y no como un "simple" dialecto del español" ("Sobre el origen" 109). 
escrita y decodificación científico-crítica que organiza vertebralmente esta investigación, constituye una nueva puesta a punto del discurso especializado sobre Palenque, a partir del cual los mismos palenqueros han reinventado incesantemente su tradición. Este artículo se inscribe dentro de un debate crítico relativamente reciente, a la vez que revisita la producción palenquera desde una perspectiva interdisciplinaria que potencia el análisis socio-semiótico y cultural. Nuestra labor aspira a representar un nuevo territorio ganado a la homogenización e invisibilización de la diferencia instalada por la crítica oficial. En torno a esta problemática, Martin Lienhard publicó en 1992 La voz y su huella. Estructura y conflicto étnico-social en América Latina (1492-1988), un texto fundacional sobre las literaturas otras o alternativas de América Latina, expresión de las "subsociedades marginadas" cultural- y socio-racialmente del continente. ${ }^{3}$

Por otra parte, abordar la literatura oral palenquera nos lleva a considerar el contrapunto naciones culturales-naciones políticas, porque esta comunidad afrocriolla asentada hace más de trescientos años a unos sesenta kilómetros de Cartagena de Indias constituye un producto creolizado del encuentro colonial que ha resistido a los procesos históricos de la conquista y colonia, y que incluyen la trata negrera, la esclavitud, la máchina plantación (Benítez Rojo) y la persecución. En medio de estas circunstancias límite, esta comunidad ha preservado parte de su memoria histórica, sus costumbres y rituales, a la vez que ha desarrollado un código lingüístico propio: la lengua palenquera. A esta condición heterogénea de su identidad cultural diacrónicamente entendida, se superponen circunstancias sincrónicas, como el hecho de pertenecer al Municipio de Mahates del Departamento de Bolívar, en el Caribe colombiano y, adicionalmente, el reciente reconocimiento global. Así, se superponen la aldea, la región, el país y el mundo en un juego de representaciones y autorrepresentaciones identitarias. Nuestra tarea se dirigirá a describir y tratar de explicar este mundo, analizando los elementos hispanos, los congoleses y aquellos desarrollados in situ por esta comunidad caribeña, sin olvidar que los palenqueros llevan siglos en Colombia y son antes que todo colombianos, o sea portadores de una cultura propia e innovadora, bien distinta de las europeas y

\footnotetext{
Allí analiza tres áreas culturales: la mesoamericana, la andina y la tupi-guaraní desde la colonia hasta finales del siglo XX, así como el carácter hipotextual y dialógico de estas literaturas orales en buena parte de la literatura latinoamericana escrita en español, desde Guamán Poma hasta José María Arguedas. La propuesta del diálogo intercultural de Lienhard en la base de la expresión americana, se toca con la noción de hibridación de tiempos y visiones del mundo de García Canclini (Culturas híbridas) y el supersincretismo de ritmos de Antonio Benítez Rojo (The Repeating Island). Recientemente, Lienhard se acercó al mundo afrolatinoamericano con dos publicaciones: $O$ mar e o mato. Histórias da escravidão (2005) y Disidentes, rebeldes, insurgentes. Resistencia indígena y negra en América Latina (2008), en donde analiza a partir de testimonios de esclavos fugitivos del régimen colonial portugués y español, en diálogo con los archivos históricos, el agenciamiento cimarrón involucrado con la fundación de los palenques y quilombos en América.
}

$111 \frac{\text { Revista Iberoamericana, Vol. LXXXII, Núms. 255-256, Abril-Septiembre 2016, } 507-549}{\text { ISSN 0034-9631 (Impreso) }}$ 
africanas. Consideramos la prácticas discursivas palenqueras como una inscripción local-subcampo cultural y artístico del Caribe colombiano- del gran relato centrífugo global afro-diaspórico (Gilroy, Black Atlantic), cuya reciente patrimonialización se inserta en una especie de movimiento centrípeto de reinvención identitaria.

Para emprender el análisis sociosemiótico cultural de la oralitura de la comunidad afrocriolla palenquera debemos trabajar sincrónicamente a la luz de los textos performáticos recogidos en campo, complementados por algunas fuentes escritas fijadas por otros investigadores (Escalante; Patiño Roselli cit. en Friedemann; Schwegler, "Chi ma nkongo 1996; Pérez Miranda, Chitieno) y por algunos textos de circulación massmediática, como la canción popular, sin perder de vista la diacronía de la memoria de las genealogías afrodiaspóricas y de los legados eurodiaspóricos. En el corpus así constituido, podemos observar una marcada heterogeneidad ética y estética en la cual la supervivencia de elementos marcadamente premodernos y genealógicamente tradicionales -sobre todo visible en los cuentos moralizantes como "María Catalina Loango", "La mata de ajíes", "Tía zorra y tío Conejo" o en el canto fúnebre del lumbalú-, convive con imperativos modernos y tics massmediáticos, especialmente visibles en la canción popular y en los relatos autobiográficos.

El estudio de la tradición oral palenquera como obra artística verbal (Bachtín, "El problema") problematiza varias de las instituciones literarias, desde la categoría de autor (individual vs. colectivo), la de obra (acabada y única vs. infinitas versiones), la de estilo (humilis, medius, grandiloquus) y género (deconstrucción ad hoc de la definición aristotélica del género como constante semiótica y retórica), a la vez que instala varios debates (lingüísticos, semióticos, sociales y culturales), como el de oralidad/escritura (Glissant), cultura popular/alta cultura (Storey), folklore/literatura/ oralitura (Martín Barbero, De los medios; Lienhardt; Niño, Etno literatura), texto literario/texto cultural (Cros), mito/historia, práctica artística/práctica ritual, local/ global (Mignolo), modernidad periférica/ posmodernidad, la academia/el mundo, entre otros. Mientras que el texto oral es un texto legible -apto para el consumo rápido y fácil (Barthes, S/Z; Image) - para el público palenquero, en tanto el relato tradicional construye su efecto a partir de la reiteración de una diégesis, un ethos y un nomos conocido y compartido que circula en los cauces del lenguaje formulario propio de la estructura épico-narrativa; para el público exogámico es texto escribible -no apto para el consumo complaciente-porque incluye palabras intraducibles, code switching, traducción cultural, glosolalia.

En cuanto a su naturaleza discursiva, el texto oral se podría definir como un constructo poético, dado que en su producción se implican elementos paralingüísticos -como la proxemia, la kinesia, la entonación y el ritmo-que se suman a la dimensión pragmática de la puesta en escena, cuando en una dinámica interactiva el locutor retroalimenta el relato base con la participación de la audiencia o con sus propias

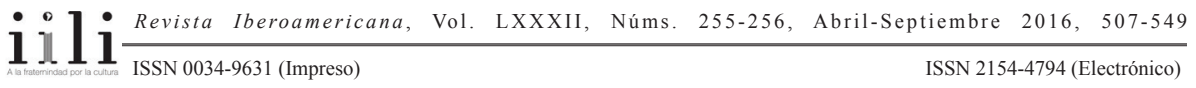


preguntas retóricas que intercala para incrementar el suspenso o la emoción del público. ${ }^{4}$ Sin duda, la oralidad desborda los límites que imponen las instituciones retóricas como la del género: el locutor es altamente propositivo en el momento de "performar" su repertorio, de modo que se producen desviaciones de la norma literaria esperable. Resultará útil entonces observar cómo el acto de habla embraga y desembraga estilos verbales y funciones lingüísticas, de modo que frente a lo esperable desde el canon literario - que la poesía sea emotiva y autotélica, el relato sea referencial y el drama dialógico-, aparece el impromptu de la oralidad que discurre por cauces inéditos. En la tradición oral es frecuente el deslizamiento de un género a otro, así como la incrustación de módulos textuales nacidos al calor de la improvisación (el chiste irrumpe en la conversación, la anécdota, el cuento o la canción en la historia de vida, etc.). Por otra parte, tienen lugar múltiples injertos de categorías discursivas en medio de los géneros tradicionales, que en el momento altamente poiético de la performance frente al auditorio (o al interlocutor científico) se suman a la adaptación del texto a las circunstancias discursivas y contextuales, así como a la recursividad propia de la improvisación con la que los palenqueros suplen los vacíos de la memoria recurriendo al auxilio de los topoi o lugares comunes del patrimonio cultural local.

\section{Memoria, mito E Historia}

Nina de Friedemann señala cómo a pesar de los esfuerzos imperiales por desintegrar las comunidades africanas en la trata esclavista en América y rearticular los contingentes negros por lotes mezclados, no se pudo impedir la supervivencia de su memoria sociocultural que tarde o temprano volvería a reunir a los afrodescendientes y darles pertenencia comunitaria ("En terrenos de la diáspora"). Para el caso colombiano, el discurso antropológico ha hablado de huellas de africanía ${ }^{5}$ (en la música, la danza, la cocina, la religión, el ritual, la tradición oral, etc.) que se extendieron desde los grupos afrocolombianos hacia el resto de la nación y formaron parte de la identidad nacional, aunque no siempre se le reconozcan sus orígenes. Reconocer las células semióticas de la tradición oral afrocriolla cumple la doble función de permitir un análisis intrínseco de las microexpresiones locales y a la vez establecer unos estándares que permitan reconocerlas en las macromanifestaciones nacionales hasta donde se ha extendido el poder de africanización.

\footnotetext{
4 Sin duda, fijar por escrito la tradición oral de una comunidad viva constituye una práctica paradójica: por una parte se salvaguarda el patrimonio cultural del olvido, pero por otra, se pierden algunos elementos propios del acto de habla, como el registro paralinguístico de los gestos y la entonación.

5 Para la genealogía del término etnogénesis, Friedemann ("En terrenos de la diáspora") remite a Bateson (Steps to an Ecology of Mind 169).
}

$111 \frac{\text { Revista Iberoamericana, Vol. LXXXII, Núms. 255-256, Abril-Septiembre 2016, } 507-549}{\text { ISSN 2154-4794 (Electrónico) }}$ 
Al analizar las formas de narrar del discurso oral (Benjamin 87; Arroyo 40), observamos cómo el narrador construye la illusio, se pierde en su diégesis y mantiene distancia con su audiencia, a la vez que negocia entre la memoria y la historia presentando los hechos y los significados artísticamente y discurriendo entre la verdad y la ficción para producir su efecto mágico (Clifford 25). Las incoincidencias entre el mito y el discurso histórico en relación con los relatos fundacionales de San Basilio de Palenque que el relato científico ha descalificado (Schwegler, "Sobre el origen"), no hacen más que reconfirmar la necesidad de otorgar a la mitopoíesis una funcionalidad distinta, comenzando por su rol estructurador de la memoria afrodiaspórica. La oralidad ha tenido un valor ontogenético, dado que se encuentra en el origen mismo de la historia literaria ${ }^{6} \mathrm{y}$ un valor filogenético, puesto que ha caracterizado de manera estructural diversas prácticas discursivas, como las de las comunidades orales de las sociedades tradicionales, de las cuales San Basilio de Palenque es un magnífico ejemplo.

La oralitura constituye sin duda una cardinal estrategia de resistencia y preservación de paradigmas ético-estéticos afrodiaspóricos que se instituirá en elemento de cohesión social y cultural. Por otra parte, el texto oral en las sociedades tradicionales como la palenquera cumple con una función ritual de reconexión con el tiempo original $a b$ origine de la fundación y cosmización de la comunidad. De modo que su funcionalidad simbólica conjura la calamidad histórica por la remisión a la fuente de toda vida (arché) y de todo ser. Estas prácticas discursivas también funcionan como motor identitario (Hall y Du Gay) que en cada acto de habla reconfirma la legalidad vigente en un entorno evidentemente distinto de la patria prototípica africana, en el contexto creolizado del territorio americano (etnogénesis de Bonfil Batalla, "La teoría del control cultural"). Así las cosas, vemos que hay un largo camino de "secularización" desde el antiguo significado antropológico y religioso de estas manifestaciones discursivas hasta su inscripción como espectáculo de consumo global-local, especialmente en el caso de San Basilio de Palenque.

El hecho de registrar la oralitura palenquera en sus múltiples manifestaciones, incluyendo el fenómeno del continuum creole y de diglosia (kateyano-lengua) dentro del campo literario nacional, que a pesar de su diversidad lingüística (setenta lenguas indígenas y dos lenguas criollas) ha estado signado desde los comienzos de su historia por la hegemonía de la lengua española, el culto del "buen decir" y una larga historia de gramáticos y filólogos, ${ }^{7}$ no sólo representa una nueva incursión en el estudio de las lenguas y comunidades afrocriollas del país, impulsado desde la Constitución de 1991 y la ley 70 de $1993^{\circ}$ por medio de las cuales el Estado reconoce y garantiza

\footnotetext{
Ver la larga historia de la llamada Cuestión homérica.

Como reconoce Carlos Patiño Rosselli ("El lenguaje de los afrocolombianos").

8 Esta ley propició la creación de una División de Investigaciones Afrocolombianas en el Instituto Colombiano de Antropología.
} 
derechos y visibilidad a las comunidades afrocolombianas, sino un paso más allá hacia el estudio de la significación del mundo que vehiculan estas prácticas discursivas en tanto arte verbal. ${ }^{9}$

\section{Oralitura y Oratura PaLenQuera}

El neologismo "oralitura" -oraliture en francés- constituye para Fall un nuevo término que, por oposición a "literatura", designa textos orales como leyendas, cuentos, epopeyas, cantos y otras producciones artísticas verbales orales menos codificadas en cuanto a su género. La oralitura, por otra parte, constituye no solo una manera de documentar el pasado, sino un sistema de conocimiento y transmisión ligado a los orígenes mismos de la historia literaria, pero de relativamente reciente visibilización en América Latina. Se ha hecho referencia a ella como tradición oral, oralitura (Fall), orature (Hagège) ${ }_{10}^{10}$ etnotexto (Niño), etnoficción (Lienhard), etnopoesía (Fichte), etnocrítica (Krupat), etc. En relación con la dificultad de circunscribir este campo ligado a los orígenes mismos de la historia literaria, pero de relativamente reciente visibilización en América Latina.

El texto oral, como señalamos anteriormente, tiene una fuerte inscripción del nivel pragmático, una eficacia ritual y se completa dialógicamente en la recepción. Constituye una entidad que se puede ver como producción, "desde su orilla" en términos de Hugo Niño, "desde la otra orilla", vale decir, desde el análisis letrado de la producción o desde ambas, sincrónicamente, en diglosia como en el caso del escritor peruano José María Arguedas. A su vez, el texto oral tiene autoridad, dado que representa una instancia cognitiva que le otorga la tradición de su nación cultural. Por otra parte, tiene un alto contenido ético-didáctico en tanto es un perpetuador de la axiología comunitaria. Muchos de ellos están asociados a mitos etiológicos y cosmogónicos, de modo que explican el origen de fenómenos y objetos del mundo. Por esta razón es complejo separar el contenido estético del contenido ético-cognitivo.

Cabría señalar que entre la oralitura palenquera y la oralidad africana elaborada (la orature de Hagège, que incluye la oralitura y las opiniones metalingüísticas de los locutores) con la cual está relacionada por habitus genealógico, se puede apreciar un

9 Los mismos lingüistas dedicados al tema han otorgado un lugar preeminente al estudio de la tradición oral para acceder al conocimiento del lenguaje afrodescendiente (Patiño, "El lenguaje de los afrocolombianos"). Germán de Granda (Estudios sobre un área) realizó una tipología de las diferentes expresiones de la tradición oral en el Pacífico entre las que distingue los géneros versificados como la décima, el romance, el arrullo, el alabao; géneros chicos como el proverbio y las fórmulas de hechicería y magia y géneros en prosa como el cuento, el mito y la narración histórica.

$10 \mathrm{Al}$ respecto, ver el comentario de Yves Moñino: "Claude Hagège ha propuesto [...] llamar "oratura" este tipo de oralidad no espontánea sino retórica, pensada, que, lejos de reducirse a la oralitura o literatura oral, la contiene como una de sus partes" ("Pasado, presente y futuro" 206).

$111 \frac{\text { Revista Iberoamericana, Vol. LXXXII, Núms. 255-256, Abril-Septiembre 2016, } 507-549}{\text { ISSN 2154-4794 (Electrónico) }}$ 
proceso de desacralización de la práctica discursiva, dado que el carácter simbólico y ritual ancestral entronca con variadas funciones comunicativas en el texto oral palenquero, como la creciente performance de la identidad, la función autonímica y la función autotélica del arte verbal implicado en procesos de oralidad secundaria (Ong, Orality), con implicación de medios masivos nacionales e internacionales. ${ }^{11}$ Sin duda, esta transición pide una plataforma interdisciplinaria de acercamiento crítico que parta desde los repertorios, descripciones y reflexiones de la lingüística, la antropología y la etnografía -ciencias pioneras en su interés por la oralidad-, y llegue hasta el análisis socio-semiótico cultural con explotación de la densidad semántica de los textos seleccionados.

Los productos de la oralitura palenquera, si bien son difíciles de clasificar dentro de un género canónico, siguen unos cauces de representación tradicional. No así las historias de vida, que podríamos asociar a lo que Néstor García Canclini llama narrativas hibridas, como estrategia de entrada, representación y negociación de la modernidad (Culturas híbridas). Clasificamos la producción textual palenquera ${ }^{12}$ como práctica discursiva (Foucault) heterogénea (Cornejo Polar) que fluye desde la oralidad primaria de la cultura popular (Martín-Barbero, De los medios) revaluada como parte estructural del complejo campo artístico-cultural socioracial latinoamericano (Losada), resistente a la otrificación del panóptico colonial (Mignolo, Historias locales) que dictamina las directrices de inclusión/exclusión de lo que se entiende por arte, cultura, literatura. Retomamos en nuestro análisis la agenda problemática (Cornejo Polar, 1994) que enfrenta el pensamiento latinoamericano y la teoría literaria contemporánea, aceptando el cambio en la noción de literatura que anunciara en los años 70 Carlos Rincón y desde una definición posicional (Hall) y no estrecha de identidad/identificación en America Latina y el Caribe (Pizarro) que registra la literatura transculturada (Rama), creolizada (Dash), híbrida (García Canclini), otra.

No olvidemos que si bien estos relatos tienen un autor anónimo-colectivo que se hunde en la tradición, a la vez poseen una instancia artística de autoría individual que va atada al momento de la actuación. Aquí cabe la pregunta entonces de cuáles son los límites entre una composición simplemente mimética, que habla de las experiencias cotidianas con muy bajo grado de codificación literaria y una composición ficcional con base tradicional. Por otra parte, la tradición oral también alimenta la obra de aquellos autores que se podrían clasificar como "un tipo bastardo de narrador", el autor-escritor que escribe la subjetividad cultural de sus naciones (Arroyo). En ellas, la figura del autor individual se desdibuja detrás de la voz del narrador cultural, como en los casos de los compositores como Francisco Cañate "Sikito", Rafael Cassiani Cassiani,

\footnotetext{
11 Ver Knowles-Borisha, Monye, Okpewho, Abdul-Rasheed.

12 Que ofrece nuestro corpus no de manera exhaustiva, pero sí altamente representativa.
}

$111 \frac{\text { Revista Iberoamericana, Vol. LXXXII, Núms. 255-256, Abril-Septiembre 2016, } 507-549}{\text { ISSN 2154-4794 (Electrónico) }}$ 
Justo Valdez o Bernardino Pérez Miranda. Podemos pensar con cierto derecho que el imaginario cimarrón creolizó el pensamiento simbólico transmitido en los relatos tradicionales españoles ${ }^{13} \mathrm{y}$ congoleses y se alimentó en esas fuentes tanto en sus fugas tierra adentro como en sus palenques camuflados en el monte. El esclavo fugitivo no sólo realizaba movimiento en el espacio - desde el adentro de la plantación hacia el afuera del monte-, sino también un movimiento en el tiempo; muchos pensaban que el camino al monte era un retorno a África (Navarrete). De modo que no podemos repetir el eslogan: San Basilio de Palenque es "un pedazo de Africa en América", ${ }^{14}$ sino empezar a entender que la comunidad palenquera es un producto creolizado altamente energético del encuentro colonial y muestra evidente de la pluralidad del continente americano, como lo muestra su repertorio oral. ${ }^{15}$

\section{REPERTORIO}

Si bien nuestro extenso corpus ${ }^{16}$ incluye un repertorio de varios géneros en verso y prosa, ${ }^{17}$ la presente selección se concentrará en el análisis de algunos géneros representativos, como el cuento tradicional, las coplas y décimas, el lumbalú y la conversación. Cada uno de ellos pide un acercamiento particular con una adecuada decodificación de las instituciones retóricas y literarias que los cifran. Por otra parte, hay que tener en cuenta que la situación de diglosia lingüística imprime una singular superposición de vías discursivas por las que el hablante discurre sin esfuerzo. Sin embargo, existen unos códigos comunitarios que hacen que el uso de la lengua se establezca en distribución complementaria. ${ }^{18}$ Ahora la lengua, además de ser un medio de comunicación, es continuo objeto de referencia ${ }^{19}$ e incluso de puesta en escena identitaria.

${ }_{13}$ En el marco de la economía de habitación (Chaudenson) que caracterizó a la sociedad esclavista en las colonias españolas de los siglos XVI a XVIII, los esclavos vivían con sus amos y tenían un acceso directo al castellano y a la cultura hispánica de los colonos, quienes a su vez integraron parte de las cosmovisiones africanas de sus esclavos. De ahí, y de la aculturación indígena en el campesinado mestizo, nació la nueva sociedad caribeña.

14 http://news.bbc.co.uk/hi/spanish/specials/2007/esclavitud/newsid_6449000/6449515.stm

${ }^{15} \mathrm{La}$ oralidad, afirma Glissant, tiene la función de inscribir la diversidad en las sociedades poscoloniales, frente a los archivos letrados de la lengua escrita (97-98).

${ }^{16}$ La investigación in extenso se podrá consultar próximamente en el libro: Maglia, G. y Moñino, Y., Kondalo pa bibí mejó. Contarlo para vivir mejor: Oratura y oralitura de San Basilio de Palenque, Colombia (En prensa).

17 Poesía (décimas, coplas y juegos de velorio), cantos y canciones, cuentos, anécdotas, conversaciones y diálogos, chistes e historias de vida, dichos y refranes, adivinanzas, duelos oratorio y hablas disfrazadas.

${ }_{18}$ Hace unos años, el palenquero no hablaba su lengua fuera del poblado, porque era objeto de discriminación, situación que se ha revertido luego de la patrimonialización de la UNESCO.

${ }^{19}$ Función autonímica del lenguaje.

$111 \frac{\text { Revista Iberoamericana, Vol. LXXXII, Núms. 255-256, Abril-Septiembre 2016, } 507-549}{\text { ISSN 2154-4794 (Electrónico) }}$ 
Nuestra iniciativa en relación con la recolección, sistematización y análisis de la oralitura palenquera tuvo antecedentes a lo largo de la segunda mitad del siglo XX. Los primeros cuentos palenqueros fueron publicados por Aquiles Escalante en 1954 quien en el prólogo a su libro Notas sobre el Palenque de San Basilio habla de la "necesidad de elaborar una antropología del cimarronaje" (s/p.). Su etnografía pionera sobre la comunidad palenquera será tomada como punto de partida de muchas investigaciones posteriores. El corpus de Escalante reúne diez cuentos recogidos por el autor, la mayoría relatados por Abel Padilla, informante palenquero de 58 años, maestro de obras, agricultor y cordelero. Carlos Patiño Rosselli y Nina de Friedemann publican en 1983 Lengua y sociedad en el Palenque de San Basilio. El volumen incluye al final un corpus de textos orales palenqueros de alrededor de veinte informantes, recogidos en trabajo de campo por Patiño. La muestra incluye varios géneros discursivos como historias de vida, historias jocosas, cuento folklórico, habla infantil y lumbalú. Armin Schwegler publica en 1996 los dos tomos de "Chi ma nkongo". Lengua y ritos ancestrales en el Palenque de San Basilio, en donde realiza el estudio más completo que hay sobre el lumbalú, rito funerario palenquero de procedencia afrodiaspórica. El volumen reúne y analiza desde una óptica socio-lingüística y cultural un corpus significativo de lumbalúes, algunos recogidos por el autor (inéditos, o ya publicados por él) y otros previamente publicados por otros investigadores. El libro concluye con un inventario de lumbalúes y un glosario de palabras rituales. Recientemente, Bernardino Pérez Miranda, nativo de san Basilio y profesor de lengua palenquera en el colegio del poblado, publicó Chitieno lengua ku ma kuendo. Hablemos palenquero a través del cuento (2009) y primera publicación que reúne cuentos palenqueros en su lengua original, traducidos al español e ilustrados por los estudiantes del colegio INSETA Benkos Bioho de Palenque. Incluye siete cuentos tradicionales en lengua palenquera y está acompañado por un estudio introductorio de Yves Moñino (CNRS, Francia).

Por su parte, los relatos orales que incluimos entran dentro de la categoría de cuento popular o tradicional (Lida de Malkiel), origen histórico del cuento literario (aunque desde la antigüedad ha convivido con él), y asociado genéticamente a la conciencia mitopoiética de las sociedades tradicionales, de la cual fluyen en un tránsito de desacralización desde el relato sagrado del mito hacia la forma profana de la leyenda, que presentará rasgos arquetípicos universales. ${ }^{20}$ Dada su funcionalidad filosóficoreligiosa de origen, el relato tradicional tiene un componente fabuloso, religioso o legendario fuerte y muchas veces tiene un propósito didáctico-moralizante, impronta del ethos comunitario. Según la clasificación de Stith Thompson (cit. en Aarne), una parte importante de los cuentos palenqueros pertenecerían a la categoría narraciones

${ }_{20}$ Véase el concepto de monomito del mitógrafo norteamericano Joseph Campbell en el (El héroe de las mil caras) y la estructura tripartita de la aventura heroica: separación, iniciación y retorno.

$111 \frac{\text { Revista Iberoamericana, Vol. LXXXII, Núms. 255-256, Abril-Septiembre 2016, }}{11}$ 507-549 
o cuentos locales que relatan hechos extraordinarios considerados verídicos, de carácter maravilloso, religioso, realista o histórico, asociados a un lugar, un edificio o un accidente geográfico. La diferencia entre cuento y relato tradicional o mítico es que el primero es invención, mientras que el segundo es verídico. ${ }^{21}$

Para los textos poéticos, debemos tener en cuenta la singular ecuación entre subjetividad y colectividad del texto oral, puesto que en ellos el autor individual (cuya hipervaloración ha sido postulada por la historia literaria) está mediado por el sujeto cultural y por el texto cultural (Cros), dimensiones colectivas vehiculadas por la tradición. Adorno señaló tempranamente que la lírica no se agota en la enunciación de experiencias subjetivas, sino que éstas sólo llegan a ser artísticas si participan por medio de su peculiar apuesta estética- de lo general, gracias a su capacidad no gregaria, no institucionalizada y no vigilada socialmente de decir lo humano (54). Vale decir que la poesía con su lenguaje icónico, su función autónoma (Mukarovsky) y su aprovechamiento musical del lenguaje estructurado sobre el principio de retorno (Jakobson, Ensayos), se opone a la doxa y enfrenta lo que Adorno llama la fuerza igualadora de la persocialización para expresar lo social por lo individual. En nuestro particular recorte textual del corpus palenquero, analizamos formas poéticas tradicionales como las coplas y las décimas; la décima es una estrofa de diez versos octosílabos con rima consonante; la copla, en sentido amplio designa una composición poética breve que puede incluso servir de letra a la canción popular, mientras que en sentido estricto, alude a una estrofa de cuatro versos octosílabos o menor número de sílabas, con rima asonante en los pares.

La conversación, placer fugaz y en vías de extinción en la aldea global (Mc Luhan, The Gutenberg; Understanding Media; et al.) sigue representando un momento de alta productividad textual en la aldea rural, particularmente en el Caribe, en donde predomina la cultura de "vitrina pública" y todo pareciera ser visible o audible (González Echavarría, "Guillén”), espectacular²2 (Benítez Rojo), con fuerte dimensión colectiva y verbal. Como género discursivo, la conversación ha generado nuevas aproximaciones en el campo del análisis del discurso (Goffman, Interaction; Forms of Talk; Gumperz, Directions; Discourse Strategies; Engager), con el fin de explicar su peculiar naturaleza

\footnotetext{
21 A partir de ejemplos levantados en la comunidad afroamericana del Harlem, William Labov habla de una estructura constante en el relato natural -oral e improvisado- que consta de seis partes: prólogo, orientación, acción envolvente, valoración, resolución y coda o epílogo (Language in the Inner City). La reflexión pionera sobre el tema es el modelo estructural del relato de Vladimir Propp quien, a partir del cuento popular ruso, señala 31 funciones y siete esferas de acción que subyacen a los relatos tradicionales y cobran cuerpo en diversas manifestaciones discursivas. Detrás de unos roles y unas secuencias de acción básicas que se reiteran bajo diferentes historias y personajes, los cuentos tradicionales vehiculan una impronta ética de carácter colectivo, cuya génesis está sellada a la comunidad de origen (Brioschi y Girola, Introducción 204 ss)

22 Léase "teatral".
}

$111 \frac{\text { Revista Iberoamericana, Vol. LXXXII, Núms. 255-256, Abril-Septiembre 2016, } 507-549}{\text { ISSN 2154-4794 (Electrónico) }}$ 
dialógica ${ }^{23}$ y performática, su “énfasis en el alocutario” y en la situación alocutiva con remisión simultánea a varios marcos de referencia (Ducrot y Todorov 348); su intensa recurrencia a la función metalingüística y a la función fática (Jakobson, Ensayos), así como su peculiar utilización de las formas interrogativas con alta ocurrencia de preguntas retóricas. En El arco y la lira, Octavio Paz define la poesía como una tipología discursiva determinada por el ritmo y la imagen. En efecto, trátese de poesía popular-de producción y difusión oral-o de poesía escrita, ${ }^{24}$ el peculiar juego del nivel prosódico y el nivel retórico del lenguaje ponen en marcha la máquina poética e intensifican los significados de la lengua, generando nuevos efectos de sentido, imprevisibles para el código gregario (Barthes, El placer).

Entre las canciones y cantos tiene un lugar cardinal el lumbalú (Schwegler, "Chi ma nkongo"). Los rituales funerarios constituyen una práctica central en la vida comunitaria de sociedades tradicionales, como la de San Basilio de Palenque. El lumbalú [> kik. prefijo $l u+$ mbalu' 'memoria, recolección, pensamiento' (Schwegler, "Chi ma nkongo" 57)] es una ceremonia mortuoria ancestral que incluye canto y danza y en general fiesta, en el sentido que da a la palabra la antropología de las religiones. Los rituales fúnebres afrocaribes se caracterizan por las novenas: nueve noches durante las cuales se vela al muerto y se danza el lumbalú, en un ambiente social acompañado de comida, bebidas y agitada actividad verbal. Los "juegos de velorio" son cantos de contenido lascivo que se prolongan durante el sepelio, en los que se destacan rítmicamente los apóstrofes e interjecciones de carácter sexual o escatológico (Escalante 83-87; Schwegler, "Chi ma nkongo" 518). El lumbalú, o 'baile e muetto', es el conjunto de cantos y de bailes que acompañan en las ceremonias fúnebres al sonido de los tambores. Pone de manifiesto las creencias religiosas palenqueras, de origen sincrético, en especial relacionadas con los misterios de la muerte, el tránsito a la vida de ultratumba y la supervivencia del espíritu. Su carácter sacro explica las palabras arcaicas, dado que la consagración de un lenguaje lo inmoviliza en una forma "auténtica" que se debe presentificar (no repetir, sino hacer presente otra vez) en cada ritual. Es precisamente su condición de "verdadero" la que lo vuelve eficaz. Constituyen a la vez el lamento del ser humano por la pérdida de la vida, la condolencia de la gens y el acompañamiento de las almas en el difícil desprendimiento de este mundo. Su estructura retórica basada en el principio de retorno prosódico, sintáctico y léxico-semántico, crea un efecto psicotrópico a través

${ }^{23}$ Literariamente, el diálogo tiene una antigua historia, desde los diálogos socráticos escritos por Platón, los célebres diálogos ciceronianos y los diálogos satíricos de Luciano de Samosata, las églogas de Virgilio y las sátiras de Horacio hasta los debates y guerras de insultos (flytings) medievales. Recientemente, los escritos de Bachtín han aportado la noción de dialogismo para el análisis literario de la novela (Preminger y Brogan 290-91).

${ }^{24}$ Esta distinción procede especialmente de la literatura medieval europea, que distinguía entre la producción de juglaría o popular y la de clerecía o culta.

$111 \frac{\text { Revista Iberoamericana, Vol. LXXXII, Núms. 255-256, Abril-Septiembre 2016, } 507-549}{\text { ISSN 0034-9631 (Impreso) }}$ 
de diferentes clases de repetición, hecho que ubicaría el estatus estético del lumbalú entre el discurso poético y el discurso religioso, cuyos límites son por cierto ambigüos (Greimas, Ensayos).

\section{Cuento}

Los tiempos narrativos ${ }^{25}$ de la clasificación de Weinrich configuran el mundo narrado propio de la épica, el cuento y la novela. El contenido que expresan debe ser entendido como un relato que nos llevará fuera de la circunstancia comunicativa (exteridad de la situación inmediata) y fuera del yo (alteridad de los papeles representados), para transportarnos al heterocosmos de la diégesis. El mundo del cuento tradicional, de génesis y transmisión oral y eventual fijación escrita es, en efecto, otro universo semántico al que nos traslada el siempre amable momento de la narración. En tanto oyentes o lectores del relato, adquirimos un instantáneo derecho a distraernos de nuestra problemática vital -sin tener que comprometernos directamente en los sucesos narrados- y a disfrutar relajadamente de esa fuga en el tiempo, el espacio y el actor (Weinrich, Estructura 66 y ss).

En la tipología de Propp la narración parte de una carencia, una pérdida o un daño que tiene al héroe, en el estado inicial, disjunto de su objeto de valor. ${ }^{26}$ En el camino de las pruebas, habrá ayudantes mágicos y ogros que favorecerán o entorpecerán la acción afirmativa, un objeto mágico sin el cual es imposible la victoria, unas leyes y prohibiciones que serán transgredidas, además de combates, catábasis, ${ }^{27}$ anagnórisis ${ }^{28}$ y hierogamias místicas, ${ }^{29}$ de tal modo que el desenlace concluye generalmente con el retorno a la comunidad de origen, la satisfacción de la necesidad o reparación del perjuicio y la recompensa y cambio de estatus para el héroe, ahora conjunto con su objeto de valor. Así queda configurada la aventura heroica, cuya estructura tripartita ha sido estudiada desde mediados del siglo XX a la luz del psicoanálisis del mito (Jung; Campbell, entre otros). Los relatos palenqueros participan de la naturaleza hiperrealista del cuento maravilloso, genealógicamente asociado al mito en sus múltiples variedades. ${ }^{30}$

Mayo Katalina Luango / María Catalina Loango ${ }^{31}$ es un relato cosmogónico emblemático de los orígenes de los palenqueros, cuyo retorno a las aguas reversa

${ }^{25}$ Imperfecto, perfecto simple, pretérito pluscuamperfecto y condicionales.

${ }^{26}$ En términos de la semiología greimasiana.

${ }^{27}$ En griego, descenso al inferos o mundo inferior.

${ }^{28}$ El célebre "reconocimiento" de la tragedia clásica.

${ }^{29}$ Matrimonios sagrados.

${ }^{30}$ Hay mitos etiológicos, cosmogónicos, teogónicos, escatológicos, fundacionales, morales, etc.

31 Mayo Katalina Luango es la versión profana de un canto sacralizado de lumbalú que alude en forma esotérica al retorno a África. Lo atestigua la palabra Chimbumbe y el apellido de la heroína que es el del puerto de embarque de los esclavos procedentes del Congo, especialmente del Mayombe.

$111 \frac{\text { Revista Iberoamericana, Vol. LXXXII, Núms. 255-256, Abril-Septiembre 2016, } 507-549}{\text { ISSN 2154-4794 (Electrónico) }}$ 
utópicamente el middle passage $e^{32}$ de la trata negrera, cifrado por otra parte, en la onomástica simbólica de su apellido. En este relato está presente el tópico de la fascinación ejercida por las aguas sobre los hombres, el poder ambigüo de sus criaturas anfibias $^{33}$-en este cuento, el moján-, así como su connotación tanática para las culturas colombianas:

En la ciénaga, había un moján ${ }^{34}$ que encantaba a los humanos. Él se transformaba en lo que quisiera para engañar a sus víctimas y llevárselas a las profundidades. En su aparencia natural, el moján era pequeño, de pelo brillante, con los talones para adelante y los dedos del pie para trás. Si el moján era macho, se llevaba a una mujer para hacerla su compañera. [...]

Una tarde, Catalina se fue al arroyo a buscar agua con un calabazo. De repente, le apareció un moncholo, ella trató de cogerlo, pero éste no se dejaba. El moncholo no era sino el moján, quien intentaba encantar a Catalina para llevársela como mujer suya. Esa tarde, Catalina no regresó a su casa, ese día ni ningún otro. Había comido lo que el moján le había brindado. (Pérez Miranda 70-71) ${ }^{35}$

“Toda alimentación es una transustanciación”, afirma Gilbert Durand: "La alquimia lo ha comprendido perfectamente. Y también las religiones que utilizan la comunión alimentaria y sus símbolos" (244). Catalina comió la comida del moján y olvidó su patria de origen. ${ }^{36} \mathrm{El}$ macrouniverso de la patria-hogar es metáfora del microuniverso del yo: atraída por el espejismo de las aguas, Catalina se olvida de sí y es enajenada por

${ }^{32}$ La ruta media designa la travesía atlántica desde África a América (Gilroy).

${ }^{33}$ Como las sirenas, Escila y Caribdis y Circe en la Odisea homérica.

${ }^{34}$ El moján y su contraparte femenina la mojana son seres sobrenaturales que viven en el agua de los ríos y atraen por seducción a los niños y jóvenes para que se queden con ellos. Estas figuras son comunes a muchas comunidades rurales de Colombia, indígenas como los kogui de la Sierra Nevada (Carolina Ortiz Ricaurte), campesinas y negras. La voz es chibcha según Alario di Filippo, que cita una c.p. del padre Revollo: "El mohán es un ser mitológico, de cutis albo y rubia cabellera, habitador de arroyos, riachuelos y lagunas, donde suele propasarse con las mozas que allí se bañan, por lo que goza de fama de enamoradizo" (218). Esta semejanza hasta en los detalles físicos sugiere una influencia indígena antigua en Palenque, pero varios pueblos de Camerún y Congo tienen una figura femenina parecida (es la nkisi o 'sirena' de los Vili costeros, que encanta a los hombres; en otras partes se llama Mamíwata, del inglés Mammy Water). El moján y la mojana palenqueros tendrían pues dos orígenes culturales, amerindio y africano.

${ }^{35}$ Lo de la comida ofrecida por el moján a su víctima es específicamente koongo: durante una estadía de Moñino en Màtòòmbì, aldea dependiente de Loango en el Congo, la gente atribuyó la desaparición de un joven, salido de su casa con una toalla al anochecer, a su secuestro por una sirène -así llaman en francés local a estas dueñas submarinas del océano, aliadas de los jefes de las pueblos de pescadores vili. Pasaba el tiempo y la gente decía que había debido aceptar comida de la sirena, lo que impedía que regresara.

${ }^{36}$ En la Odisea los navegantes que pasaban por el país de los Lotófagos -Isla al Nordeste de Africa por la que pasó Odiseo- comían el loto y perdían el deseo de retornar al hogar.

$111 \frac{\text { Revista Iberoamericana, Vol. LXXXII, Núms. 255-256, Abril-Septiembre 2016, } 507-549}{\text { ISSN 2154-4794 (Electrónico) }}$ 
lo Otro, zombificada por el moján. Lo que ocasiona su peripecia es una transgresión de las leyes consuetudinarias de la gens, premonitoria de sus inclinaciones misántropas: "Catalina Loango tenía la mala costumbre de ir tarde a buscar agua al arroyo llamado Ciénaga de Palotá. Cuando las mujeres ya regresaban, apenas Catalina se iba para el arroyo" (Pérez Miranda 70-71).

En consonancia con su figura necrofílica, asociada al lumbalú, Catalina regresa de la muerte hacia el mundo de los vivos, sólo cuando la muerte llama:

Después de años, la gente del pueblo se había resignado a lo sucedido. Hasta el día que el papá de Catalina se murió. En el velorio se escuchaba un "baile de muertos" proveniente del monte cercano a la casa. Todos se sorprendieron y dijeron que era Catalina Loango que venía cantando. Ella iba cantando:

Oh, adiós María Catalina Loango, eh, ele, ele, ele lo...

Chimbumbe, ${ }^{37}$ adiós, chimbumbe, adios [...]

A los pocos meses, la mamá se murió, y llegó Catalina cantando:

Oh, adiós mi mamá, adiós, e, ele, ele, lo...

Chimbumbe, adiós, chimbumbe, adios,

e, o, adiós chimbumbe, me tragó hasta la mitad.

Ele, ele, lo, María Loango. (Pérez Miranda 70-71)

Tía Zorra y tío Conejo es una fábula palenquera en la que, por medio de la prosopopeya, se atribuyen características y acciones humanas a animales. La estructura de la historia es similar, si bien presenta algunas diferencias en las distintas variantes del relato. En la versión recogida en campo, que miraremos más de cerca, Conejo pone en escena la illusio con Zorra, para conseguir pasarla bien sin trabajar:

\{Todos los días\} Zorra buscaba gallinas en los corrales ajenos para hacerle comida a tío Conejo. \{Todos los días\} tía Zorra hacía la comida de tío Conejo. Tío Conejo solía llegar donde un palo grande y sentado ahí se comía su comida. (Miranda Hernández)

La distancia sostiene el andamiaje de la mentira, porque mientras Conejo está en el espacio tópico, ${ }^{38}$ Zorra está en el espacio heterotópico: ${ }^{39}$

${ }^{37}$ Escalante y Schwegler (“Chi ma nkongo"; "El vocabulario") traducen Chimbumbe por 'moján' o 'diablo'. Schwegler propone acertadamente la etimología kikoongo di- 'prefijo de clase $5+$ mbumba 'espíritu acuatico' (“Chi ma nkongo" 201-08). A Moñino le asociaron en Palenque la palabra con el 'Retorno espiritual a África', es decir a la muerte. En otro cuento, 'La hija desobediente', una serpiente figura como espíritu acuático, un nkisi, una 'sirena' (ver más adelante).

${ }^{38}$ Lugar de las pruebas preparatorias.

${ }^{39}$ Lugar que lo engloba precediéndolo y/o sucediéndolo.

$111 \frac{\text { Revista Iberoamericana, Vol. LXXXII, Núms. 255-256, Abril-Septiembre 2016, } 507-549}{\text { ISSN 2154-4794 (Electrónico) }}$ 
-Conejo, ¿cuándo me vas a llevar?, que todo el mundo está cortando arroz menos tú. -Te voy a llevar, te voy a llevar, para que vayas a cortar arroz también. (Miranda Hernández)

Pero el juego de la verdad ${ }^{40}$ que había montado Conejo, estructurado sobre la oposición entre el plano de la manifestación (parecer/no parecer) -en el cual la roza es de Conejo y el plano de la inmanencia (ser/no ser) - en el cual la roza es de Tigre, fue tumbado por la conversión de su adyuvante, Zorra, en oponente, cuando por error ${ }^{41}$ transforma el silencio cómplice (relación de intimidad) en la voz que delata (luz pública):

- ¡Estoy en la roza de mi marido Pedro Conejo Barrios!

-iZorra, tate quieta, Zorra, tate quieta!

-Conejo, si la roza no era tuya, ¿por qué me traiste? Si la roza no era tuya, ¿por qué me traiste? Y siempre Zorra con su cantaleta:

-¡Estoy en la roza de mi marido Pedro Conejo Barrios! Tío Conejo decía:

- ¡Zorra, estáte quieta! -Conejo, si esta roza no fuera tuya, no me hubieras traído en eso. (Miranda Hernández)

De modo que el desenlace es negativo para la pareja de pícaros, que tienen que desaparecer de la escena para siempre y desde entonces serán enemigos: ${ }^{42}$

Los perros salieron, y los perros tras Zorra, y tía Zorra corriendo, tía Zorra corriendo y los perros tras ella y tía Zorra corriendo y los perros tras ella. El cuerpo de tía Zorra quedó vuelto harapo. Y halando lo que... se enganchó el cuero de ella.

Esto pasó huyendo de los perros. Conejo quedó huyendo de tía Zorra.

Desde ese tiempo, cuando Conejo vea a tía Zorra, él no llega allí. Conejo se pone a ladrar como perro, huyendo de tía Zorra. (Miranda Hernández)

En las populares y extendidas variantes de esta fábula y de otras del mismo ciclo, Conejo representa al héroe astuto, el trickster (Jung), ${ }^{43}$ cuyo objeto de deseo es /la vida

40 Modalidad veredictoria greimasiana: ser $v s$ parecer.

41 Concepto de hamartía o "error trágico"en la tragedia clásica: el héroe no es culpable, sino que se equivoca, comete un error por ignorancia.

42 La zorra, en efecto, es predadora del conejo y de la liebre. Ese tipo de cuentos explican por qué muchos animales son enemigos, después del edén de su amistad en los principios del mundo (Moñino, "Pasado, presente y futuro").

43 En muchas partes de África el conejo de los cuentos es el arquetipo del astuto, del avispado y representa el oprimido frente al "tigre" (en realidad el jaguar en Palenque o la pantera en África) poderoso y pudiente, arquetipo del estúpido aunque temible. Son innumerables los cuentos africanos donde Pantera es la víctima de las bromas de Conejo. Este, como también Anansi, la "araña" de todo el África del Oeste trasladada al Pacífico colombiano, es un trickster, un héroe civilizador rebelde que desafía las reglas sociales y la autoridad, lo que explica su éxito en muchas comunidades negras de las dos Américas

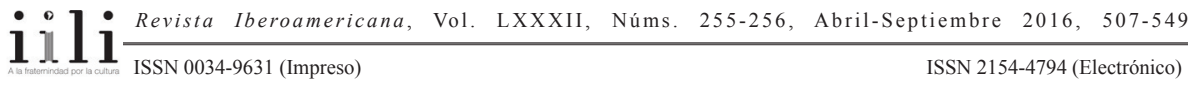


regalada/. Su adyuvante es Zorra y su oponente, Tigre, que representa el oxímoron del poderoso-bobo. Conejo es impulsado a la acción por una ética pragmática (destinador) en la cual el fin (la vida regalada) justifica los medios (el truco y la mentira). La fortaleza de Conejo es mental-estratégica, que gana frente a las fortalezas materiales de Tigre. En el contexto de las culturas afrodiaspóricas coloniales y poscoloniales, el conejo bien puede representar al subalterno que ingenia estrategias de resistencia entre la afilación y el rechazo frente al discurso hegemónico (Ashcroft, Griffiths y Tiffin).

La hija desobediente ${ }^{44}$ es un relato muy sencillo desde el punto de vista de la historia, pero simbólicamente pleno de resonancias. La acción se puede resumir en las siguientes secuencias: Irene encuentra en el río una culebra pequeña que llevó muy feliz para su casa. La culebra creció tanto que ya no cabía en ninguna parte y tuvieron que arrojarla al mar, adonde Irene iba a visitarla periódicamente. Preocupado por semejante relación, el padre encierra a la joven, pero la serpiente se las ingenia para ir a verla. Desesperado, el padre opta por mandar lejos a Irene y la embarca, inútilmente, porque la serpiente se va detrás de la nave. Finalmente Irene se arroja al mar, a instancias del capitán, alarmado por tal persecución, y queda sepultada en el vientre de la serpiente.

Retóricamente, el cuento se construye a partir de una hipérbole continuada que opera el tránsito de lo real (la culebra en su estado inicial) a lo maravilloso (una culebra que no para de crecer):

Al poco tiempo tuvo que sacarla del frasco, porque amaneció muy grande; luego la pasó para una cazuela y posteriormente para una tinaja. Se fue para la escuela y cuando regresó se halló con que el animal ya no cabía en la tinaja, cosa que obligó al padre a buscar varios hombres para sacarla; al llegar éstos se sorprendieron y exclamaron: -isi es una sierpe! ¡ Hay que matarla! (Escalante 95-96)

Sin duda el mayor núcleo de densidad semántica está constituido por la figura de la serpiente: el simbolismo ofidio es polivalente y antiguo y está asociado a sexualidad, fertilidad y muerte. Al respecto, Gilbert Durand hace un interesante rastreo comparativo:

Es este complejo de sexualidad y fecundidad lo que explica el papel de primer marido que la serpiente desempeña en numerosas culturas [...] En las culturas paleo-orientales y mediterráneas, la serpiente toma con frecuencia el lugar del falo: así Príapo es a veces ofidiforme. La unión mística con la serpiente estaba en el centro del rito de los misterios de Eleusis y de la Gran Madre. [...]. Por último, la imaginación de los poetas viene a recordar el enagrama milenario de la serpiente como primer amante $[\ldots](304-05)$

sometidas a la discriminación y a la pobreza. Pero el trickster es también en todas partes un travieso infantil que no controla siempre sus pulsiones y puede caer por imprudencia, como en el cuento 'Conejo, Sapo y Tigre' recogido por Patiño Rosselli.

${ }^{44}$ Cuento recogido por Escalante (95-96).

$111 \frac{\text { Revista Iberoamericana, Vol. LXXXII, Núms. 255-256, Abril-Septiembre 2016, } 507-549}{\text { ISSN 2154-4794 (Electrónico) }}$ 
El llamado "complejo de Cleopatra" que asocia mujer y serpiente en torno al poder pareciera relacionarse con nuestro relato, dado que el símbolo ofidio, objeto de deseo del héroe, es una fuerza centrífuga, a cuya consecución se opone la tensión endogámica, siempre centrípeta, aquí representada metonímicamente por la figura del padre. El mismo título del cuento es una apertura semántica que caracteriza al héroe desde el punto de vista de las leyes de la gens: Irene no es representada desde la ponderación de su belleza, ni de su juventud, sino desde la óptica de su desobediencia filial. Para superar el complejo de Electra, forzosamente debe ceder a la tentación de la serpiente y desatar el lazo paterno: ${ }^{45}$ "En vista del incesante afán de la niña, el padre se vió en la imperiosa necesidad de encerrarla, pero la serpiente venía a visitarla. [...] Desesperado, decidió enviarla a un lejano país; antes de partir, la chica le rogó que le permitiera ver a su culebra por última vez y como no lo consintió, lo hizo a hurtadillas" (Escalante 95-96).

\section{PoEsíA, DÉCIMA Y COPLA}

Hemos leído muchas veces que el español es una lengua grave o paroxítona que fluye -como los ríos a la mar- hacia el verso octosílabo, como podemos apreciar en el rico acervo de la poesía popular hispanófona. Con la conquista y colonización de América, llegó a nuestro continente el legado del romancero y el cancionero español tradicional, que en su fructífera aclimatación al Nuevo Mundo daría nuevos resultados, producto de los procesos de creolización. En tanto géneros populares, estos implican "las nociones de anonimato, transmisión oral y variación en la transmisión" (Trapero 115).

El riquísimo legado de procedencia eurohispánica (Menéndez Pidal 325-56; Lapesa, inter alii) de estos versos de arte menor ${ }^{46}$-la copla octosílaba de estrofa varia y la décima- ha aportado, además de la codificación prosódica, un registro léxico y ciertos tópicos recurrentes, esqueleto básico que reaparecerá con nueva morfología

\footnotetext{
45 La hija desobediente es un tema recurrente en toda África. Veronika Görög y Christiane Seydou en $L a$ fille difficile (2001) plantean para este tema un esquema matricial, o cuento-tipo, a partir del análisis de unos ciento cincuenta cuentos de todo el continente. Tienen en cuenta la diversidad de respuestas a la afirmación de sí de la mujer rebelde, la variedad que traduce la riqueza semántica y narrativa de la temática. Se trata siempre de una joven que exige escoger su esposo, cuando el matrimonio es asunto de familia: en toda África, la hija difícil cuestiona la exogamia, la autoridad tradicional, la masculinidad y la feminidad, la identidad y la alteridad. En el cuento palenquero, no se trata de oposición al matrimonio arreglado, pues las afinidades electivas son por lo general cosa de la pareja, no de la familia. Pero el cuento sí expresa la voluntad de la chica de dedicarse a su tesoro (¡una serpiente, y qué serpiente!) frente a la autoridad paterna. Y por otra parte, evoca también poderosamente el destino de Catalina Loango y el Retorno a África.

${ }^{46}$ Compuesto por versos de ocho sílabas o número menor.
}

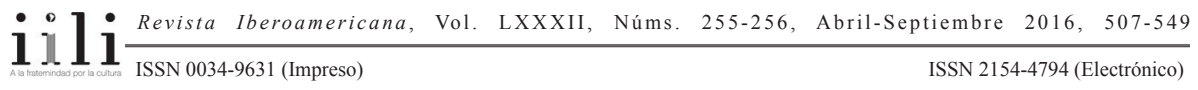


en tierras americanas. Sin duda, estos géneros tradicionales han encontrado un terreno particularmente fértil en el Caribe colombiano, como lo han mostrado los estudios de las tradiciones folklóricas en el país (Beutler; Posada inter alii). El problema consiste en otorgarles el merecido estatus literario que durante largo tiempo, parece habérseles negado en el campo literario colombiano, como señala Freja (2012).

Las coplas y décimas constituyen una manifestación artística que vehicula en su nivel ético-cognitivo, un recorte de la experiencia que arrastra evaluaciones del mundo ${ }^{47}$ previas y las revalúa in situ, al calor de la machina poética. En el caso palenquero llama la atención la adopción supersincrética ${ }^{48}$ de las coplas y décimas tradicionales hispanodiaspóricas, al lenguaje, el tono y los cuadros intertextuales del cancionero popular costeño, que vendrá a yuxtaponerse con el imaginario africano de otras producciones. ${ }^{49}$

En la décima: "Obsequio en verso" 50 aparecen los reclamos sentimentales del trovador al estilo del amor cortés, con la consabida deificación del inaccesible objeto de deseo: "ángel mío", "mi adorada", "mi cielo", "santa mía”; el carácter clandestino de la relación amorosa: "aunque tengas otro dueño, / nunca dejaré de amarte", así como la glorificación de las cualidades de la dama: "mano preciosa", "bella rosa" como corolario de la sumisión declarada del enamorado a su señora:

Tu dormida yo dejpierto parado frente a tu pieza contemplando tu belleza que en vida me tiene muerto.

$[\ldots]$

Debo vobbé a bujcarte, no puedo vivir sin verte.

Aunque me cuejte la muerte, nunca dejaré de amarte. (Cañate Cáceres)

Por otra parte, el apóstrofe con el gentilicio "costeña" permite ubicar geohistóricamente el cronotopo de la deliciosa escena nocturna de la ventana: ¡el enamorado despechado no está en Provenza sino en el Caribe colombiano!:

Saludos hermosa costeña hermosa

\footnotetext{
47 Populares y tradicionales.

48 Antonio Benítez Rojo habla de "supersincretismo" en relación con las complejas tradiciones de los Pueblos del mar que llegan al Caribe: detrás del legado mediterráneo de los imperios europeos, hay subsumidas otras epistemes, muy antiguas de Asia y África.

49 Y totalmente ausente aquí.

${ }^{50}$ Por Francisco Cañate Cáceres "Sikito".
}

$111 \frac{\text { Revista Iberoamericana, Vol. LXXXII, Núms. 255-256, Abril-Septiembre 2016, } 507-549}{\text { ISSN 2154-4794 (Electrónico) }}$ 
y aquí está tu truvador Quien te canta es tu amor por tu lira melodiosa.

Saca tu mano preciosa, salúdame angel mío, porque allí en el monte ombrío reposa la brisa vana. (Cañate Cáceres)

Todo el cuadro está nimbado por el imaginario de alcoba, aludido metonímicamente, ${ }^{51}$ de modo que queda flotando la connotación sexual configurando una isotopía erótica connotada positivamente para el /estar despierto/ y vivo para el amor, por oposición a la connotación disfórica del /estar dormido/, lejos del mundo y por lo tanto, del enamorado en la ventana:

Tu dormida yo dejpierto,

Tu dormida yo dejpierto parado frente a tu pieza contemplando tu belleza que en vida me tiene muerto.

[...]

Ecuchá, escucha este verso de tu fiel madrugador.

Aquí mismo hazme el favor de levantarte ligero.

De lo contrario mi cielo me moriré de dolor.

$[\ldots]$

Dejperta mi bella rosa, aurora de la mañana, Vino el ser quien má te ama a datte un beso en la boca. Poqqu'en tuj labio reposa el aroma de una flor. (Cañate Cáceres)

Finalmente, el amor inconsumado, deja al sufrido enamorado solo en medio del silencio, premonitorio de la muerte:

No se lo que me sucede y así no se mata un hombre.

Te llamo, no me rejponde.

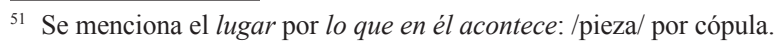


Será que ya no me quierej.

Me duele el alma, me duele.

Morirme fuera mejor.

No tengo ejte valor

para que tu sufraj tanto.

Y si me olvidaj, me encanto,

me moriré de dolor. (Cañate Cáceres)

En "Quiero besar tu cabello", ${ }^{52}$ en cambio, el sujeto libidinal expresa abiertamente su deseo en una décima cuyo palimpsesto deja adivinar una superposición de hipotextos ${ }^{53}$ en los cuales también se dibuja paso a paso el cuerpo femenino a través del trazo descendente del beso:

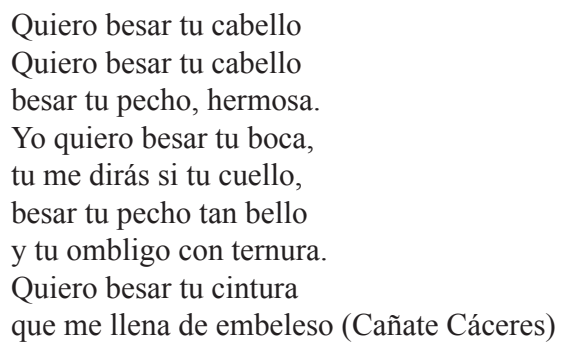

El final de esta décima deja entre líneas la noción clásica del amor morbo: el amor es una enfermedad que envenena, como las flechas de Eros-Cupido, quitando el hambre, el sueño y el aliento vital a los hombres (signa amoris): la metonimia del beso cristaliza la imagen del poder letal del amor:

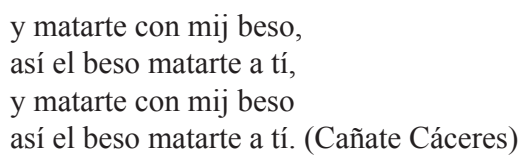

Otras composiciones recogen reflexiones filosóficas con el aire festivo propio del habitus eufórico del Homo caribbeans, como en "Palo por palo son palos":54

Palo por palo son paloj ${ }^{55}$

${ }_{52}$ Décima por Francisco Cañate Cáceres "Sikito".

53 Desde el bíblico "Cantar de los cantares" hasta "L’Union Libre" de Breton y "Besos" de Tomás Segovia.

${ }^{54}$ Por Francisco Cañate Cáceres "Sikito".

${ }^{55}$ Todos los hombres somos iguales.

$111 \frac{\text { Revista Iberoamericana, Vol. LXXXII, Núms. 255-256, Abril-Septiembre 2016, } 507-549}{\text { ISSN 2154-4794 (Electrónico) }}$ 
Ese ej la pura veddá.

Palo por palo son paloj

Ese ej la pura veddá. (Cañate Cáceres)

Luego de la reflexión inicial sobre la condición humana, aparece una pequeña escena doméstica en la que se pinta cómo los animales forman parte de la vida cotidiana en el patio familiar de la casa palenquera: el cuadro que rememora la persecución de la hicotea, animal muy preciado por su carne:

Llegó un animá pintao

se parece mapaná.

Llegó un animá pintao

se parece mapaná.

Morrocoya $^{56}$ pata pintaa

pata pintaa

[...] (Cañate Cáceres)

Para poder comprender esta pieza, es necesario recurrir a su prosodia: el catalizador de los versos truncos (tetrasílabos que ocupan exactamente un hemistiquio o medio verso octosílabo) incrementa el ritmo discursivo, instalando -luego de la sentencia de los pareados iniciales- una atmósfera de inminencia:

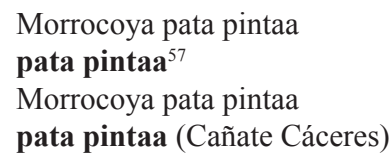

Desde una lectura semántica de los elementos formales (Lotman), asimilamos la aceleración rítmica al tempo vivacissimo del momento de la caza que, intensificado por lo inesperado de la irrupción del extraño animal en medio del sopor caribeño de la siesta, crea todo el efecto poético de esta composición, que cierra de manera inconclusa, porque su función es instalar un clima, más que contar una historia:
Compadre mande la perra aquí ronca el animal.
Compadre mande la perra
aquí ronca el animal.
Aquí tengo la cabulla

\footnotetext{
56 Tortuga muy parecida a la hicotea de tierra.

${ }^{57}$ La negrilla es mía e indica verso trunco.
} 
y ya no lo puedo amarrá.

Aquí tengo la cabulla

y no lo puedo amarrá.

[...]

Sigue ladrando la perra

viene par'acá

Llegó un animá pintao

se parece mapaná.

Llegó un animá pintao

se parece mapaná.

Morrocoya pata pintaa

pata pintaa

pata pintaa

Morroco, pata pintaa

Morroco, pata pintaa

Pata pintá. (Cañate Cáceres)

"El chocho" 58 es una pieza que configura una escenificación del asedio amoroso -no carente de picardía - a través de una metáfora botánica ${ }^{59}$ en la cual el amor es un jardín bucólico, el enamorado, el pájaro toche que viene a libar la flor, representación de la doncella:

\author{
Ayer en la tardecita, Muñe, \\ en tu jardín vino un toche. \\ Ayer en la tardecita, Muñe, \\ en tu jardín vino un toche \\ picando una florecita. \\ antej que fuera de noche, Muñe. (Cañate Cáceres)
}

El estribillo establece la advertencia sobre los peligros del amor, instalando nuevamente la dimensión del amor morbo: ${ }^{60}$
cuidese, chocho
cuidese, chocho
cuidese, chocho, hija,
cuidese, chocho.

58 "El chocho", Terapia criolla, por Francisco Cañate Cáceres "Sikito", 25 de enero de 2012.

59 El chocho (Abrus precatorius) es un "pequeño arbusto de la familia de las papilionáceas. Sus flores, de color rosado lila, crecen en racimos; su fruto consiste en una vaina aplanada que contiene numerosas semillas de color rojo, brillantes y duras. Es planta de clima cálido, y se emplea en medicina popular como insecticida y antihelmíntico (Haensch y Werner, Nuevo 139).

${ }^{60}$ Ver supra "Quiero besar tu cabello". 
Mami, ¡ay, hombe!

$¡$ ¡Ay! Mira, yo soy el toche, Muñe,

juijte quien me matajte

con la flecha de tus ojo.

E corazón me lo trappasajte.

[...] (Cañate Cáceres)

Hacia el final, la canción inscribe la dimensión social como instancia reguladora de los connubios, de tal forma que se opone /querer/ a /deber/ y deseo a realidad para confinar ese amor al territorio de lo imposible (/no poder/).

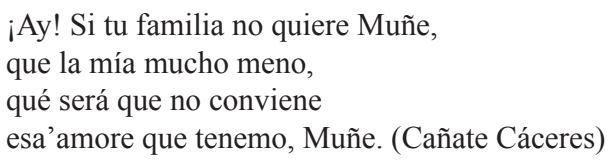

Hay composiciones como “Agua tán yobé", "Va a llover", ${ }^{61}$ que-lejos de desarrollar un hilo narrativo o una apuesta argumentativa- simplemente pintan una escena, crean un clima, instalan un termómetro afectivo, ponen en danza semántica unos significados apenas esbozados que, en constelación, producen efectos de sentido únicos. En esta décima en lengua hay una conversación familiar que pareciera un diálogo de sordos: hay varias solicitudes construidas con verbo en imperativo,

Mamá, suto tán kombetsá.

-Monasito, ¿ke jué loke bó tán jablá?

-Mamá, miní á kuchá.
Mamá, vamos a conversar. ${ }^{62}$

-Niño, ¿qué es lo que estás diciendo?

-Mamá, ven a escuchar.

hay una información importante que se debe conocer:

Papá, ay mamá, monasito si tando awé.

-Moná, miní a kuchá.
Papá, ay mamá, tu niña se va mañana.

-Hija, ven a escuchar. (Cañate Cáceres)

Y mientras tanto, de manera intermitente, entre diálogo y diálogo, caerá [?] la lluvia en estribillo pareado:

$\begin{array}{ll}\text { Agua tán yobé } & \text { Va a llover } \\ \text { i suto tán mojá. } & \text { y vamos a mojarnos. }\end{array}$

61 Décima en lengua por Francisco Cañate Cáceres "Sikito".

${ }^{62}$ Las negrillas son mías. 
Agua yobé p’i labá.

Agua yobé p'i labá.

[...]

Agua yobé, k'i tán labá

Agua yobé, k’i tán labá (tibiri tibiri, etc.)

$[\ldots]$

Agua tán yobé

$i$ suto tán mojá.

[...]
Llover para yo lavarme.

Llover para yo lavarme.

Llover, que me voy a lavar.

Llover, que me voy a lavar.

Va a llover

y vamos a mojarnos. (Cañate Cáceres)

La sensación que deja esta décima en el lector es que mientras llueve insensible y atemporalmente en el macrocosmos natural, los microcosmos de la vida cotidiana tejen sus pequeñas historias.

La poesía oral palenquera-recitada o cantada-se viene a sumar al vasto repertorio del cancionero y romancero nacional, valioso patrimonio artístico verbal históricamente desplazado hacia los inciertos territorios del folklore o blanqueado antes de su inclusión al campo literario colombiano (Freja). Es hora de hacerle justicia.

\section{CONVERSACIÓN Y DIÁLOGO}

Los recientes estudios de análisis conversacional han reemplazado el término conversación por el de "talk-in-interaction". En efecto, la conversación es considerada un prototipo de interacción con una finalidad interna -dado su carácter gratuito y autotélico-, una codificación lingüística, kinésica y proxémica acorde a patrones culturales así como al grado de formalidad de la situación comunicativa ${ }^{63}$ y un lugar de enunciación polifónico. La definen su carácter inmediato y su estructura abierta y flexible, tanto en la alternancia de los turnos de habla, como en los tópicos que vehicula, su extensión y su tono. Estas particularidades, asociadas a su débil constricción situacional, posibilitan la aparición de múltiples negociaciones conversacionales. (Charaudeau y Maingueneau 131). ${ }^{64}$

Greimas define el diálogo como "la unidad discursiva, de carácter enunciativo, obtenida por la proyección de la estructura de la comunicación en el discurso enunciado", que aparece marcada por un encuadramiento "cuya función principal es señalar el acto de habla en cuanto acto somático ("dijo él", "repitió él")" (Greimas, Semiótica 121). Como veremos en las conversaciones palenqueras, paralelamente a los enunciados portadores del tema tratado, hay gran cantidad de demarcadores de

${ }_{63}$ Formal, semiformal o informal.

64 "Las negociaciones son una adaptación por tanteo al otro y a las particularidades de su universo cognitivo y afectivo para permitir la intersubjetividad (Charaudeau y Maingueneau 404).

$111 \frac{\text { Revista Iberoamericana, Vol. LXXXII, Núms. 255-256, Abril-Septiembre 2016, } 507-549}{\text { ISSN 0034-9631 (Impreso) }}$ 
transición y segmentos-réplica que van tejiendo en la narración una compleja red de relaciones anafóricas que inscriben a menudo una abundante comprobación del canal comunicativo físico o psicológico, del estilo: “¿me entendió?”, “¿me oyó?”, etc. Vale decir, que los enunciados están cargados de un valor semántico y un valor pragmático. Veamos algunos ejemplos de nuestro corpus palenquero:

EP: $\quad[\ldots]$ Entonces, por el miedo, no podíamos decir nada. Porque entonces teníamos que cargar con otra paliza ahí en casa otra vez. ¿Entiendes? ${ }^{65}$

YM: Entiendo. [función fática]

(Padilla Ortega “Kaná” y Herera Torres)

JT: Ahora te voy a preguntar: cuando eras joven, ¿qué oficio hacías? ¿Que si qué hacías cuando eras joven? [interrogación directa]

RM: Pilar maíz para ir a vender a Malagana, a Sincerín, ahí en El Batey, ahí ese Sincerín, Malambo, a vender maíz, arroz pilado, para vender: - ¡arroz pilado y maíz blanco! Nosotros vendíamos maíz.

JT: Bueno. La gente no solía ir de aquí a Calamar ${ }^{66}$ para vender arroz, para vender a Calamar.

RM: Ajá. Dime. [función fática]

JT: $\quad\{$ Y ahora lo digo, $\}$ que mira,... [función fática]

RM: Observa, \{fijate $\}$ cómo las cosas cambian, las cosas están cambiadas. Ese es otro mundo el que la gente tiene. [función fática]

JT: De aquí, de aquí salíamos. \{Fijate, $\}$ para que veas que el mundo suele dar muchas vueltas. [función fática]

RM: ¡El mundo! Como una totuma encima del agua.

(Torres Valdez y Miranda Valdez)

FC: \{De manera\} que yo hacía maldades aquí en el barrio Junché, por esos lados. Ahora mira, ahí en la casa de... Tú no conoces a esa mujer. ¿Conoces a Timotea? [interrogación directa]

DM: \{ ¿La vieja $\}$ Timotea? [función fática e interrogación directa]

FC: Timotea, la abuela de Salvadorcito. Aquí, adentro de Palenque, aquí había un mango era ahí, \{ve.\} Ese solar que hoy en día es de Ermenehilda, aquí adentro de Palenque donde había un mango, era ahí, solo ahí.[segmento-réplica]

(Cáceres Cañate y Miranda)

JT: $\quad$ El toche chiquito lo he visto, comadre.

RM: ¿A dónde? [interrogación directa]

JT: Pregunta a Blás, para ver que Blás también lo vió. Pacho.

${ }^{65}$ Las negrillas son mías.

${ }^{66} \mathrm{La}$ isla en donde se ubica el viejo Cartagena.

$111 \frac{\text { Revista Iberoamericana, Vol. LXXXII, Núms. 255-256, Abril-Septiembre 2016, } 507-549}{\text { ISSN 0034-9631 (Impreso) }}$ 
RM: Toche chiquito.

JT: Toche chiquito. [segmento-réplica]

RM: ¡Jesús!

JT: Toche chiquito.

YM: ¿Qué es el toche? [interrogación directa]

JT: ¿Toche chiquito? De 'toche' vamos a darte esa explicación. El toche chiquito es una culebra. [función metalingüística]

YM: Ah, una culebra.

JT: Una culebra amarilla. [segmento-réplica]

RM: ¿Largo, ese toche?

JT: Eso, para que veas. [...]

(Torres Valdez y Miranda Valdez)

FC: $\quad$ Eso sí no me lo sé. No sé echar chistes.

DM: ¡Cualquier cosa!

FC: Cualquier cosa, [segmento-réplica] ¿como qué? [interrogación directa]

DM: Los chistes viejos que tú tienes.

FC: ¿Los chistes viejos de Palenque? Ajá, de aquí de Palenque. [segmento-réplica] (Cáceres Cañate y Miranda)

FC: Yo salí con mi trozo de caña. Dice José Losito: \{-¡aquí te cojo!\} ¡Vuelve a venir! Ese hijo de Cipriano y Leona es muy perjudicial.

DM: ¡Muy atrevido, carajo!

FC: Ahora mira otra cosa. Gentes estaban pescando con trapo ahí, \{ve.\} [demarcador de transición] ${ }^{67}$

(Cáceres Cañate y Miranda)

Las conversaciones de nuestro inventario están ancladas en un tiempo (antes/ ahora), un espacio (acá, en Palenque/allá, fuera de Palenque) y unos actantes (los viejos/ los jóvenes), de tal forma que, a medida que avanza el diálogo, se va configurando una isotopía eufórica del "paraíso perdido" (tempus / locus amoenus en el pasado) versus una isotopía disfórica para el tempus / locus terribilis del presente, que pone de manifiesto una visión de mundo conservadora propia de las sociedades tradicionales:

EP: Es que nosotros, antes, nuestros padres eran muy severos. No podíamos hacer cosas malas, antes no era \{por eso.\} Ahora, los jóvenes de ahora, no. Los jóvenes de ahora, si tú le pegas, te va a pegar también. O sino, sus padres te van a hacer reclamo, ¿qué hiciste a su hijo?, para pelear contigo también. Por eso es que los jóvenes de ahora no respetan a ninguno. (Padilla Ortega, "Kaná" y Herrera Torres)

${ }_{67}$ Para indicar el paso de un tema de la conversación a otro.

$111 \frac{\text { Revista Iberoamericana, Vol. LXXXII, Núms. 255-256, Abril-Septiembre 2016, } 507-549}{\text { ISSN 2154-4794 (Electrónico) }}$ 
Sin embargo, aún en ese mundo incontaminado y altamente codificado por una sólida deontología del Viejo Palenque, había unas interesantes grietas por donde el placer se filtraba y podía circular libremente, como muestra la siguiente escena que pinta desde una perspectiva aérea el bucólico cuadro de unas jóvenes retozando en el agua, bajo la indiscreta mirada masculina:

JT: Mire, \{le digo que $\}$ ahí en Casinguisito, en Casinguisito...

RM: Eh, así es.

JT: $\quad$... ahí había unas pozas, ahí está la poza Nicolo.

RM: ¡Sí señor! Yo tengo como treinta años sin no ir por allá, por la poza Nicolo.

JT: Tú no vas más por allá, por donde todas esas pozas se acabaron.

RM: Todas esas pozas se acabaron. Han pasado como cuarenta años desde que iba por allá. Éramos señoritas, nadando en esa poza.

JT: Una poza grande.

RM: Hundiéndonos y saliendo, entonces los muchachos jóvenes se escondían para mirarnos, y nosotras nadando. Jóvenes, muchachos jóvenes y nosotras nadando. Mira, eso se acabó.

JT: ¿No se ha acabado? ¡Que se acabó! La gente ya no lo ve más.

RM: Nunca lo volverán a ver.

(Torres Valdez y Miranda Valdez)

Las diferentes intervenciones revelan la nostalgia de un orden definitivamente perdido, regido por el respeto-temor de los mayores y la honra públicamente reconocida ${ }^{68}$. La justicia simétrica (culpa/castigo) ejercida por la propia mano y la noción de gentilicia de familia extendida hacen que sea la comunidad palenquera o su microexpresión, el barrio, quien se hace responsable de la paideia ${ }^{69}$. El ethos tradicional palenquero se apoya en la postulación de un ideal rústico de hombre, que vive en el ejercicio de unas virtudes cardinales. Entre ellas está el "no robarás":

EP: Antes, cuando yo era chiquito, cuando salíamos a pescar al río, cuando cortábamos racimos de plátano, para traerlos aquí a nuestras casas, era un lío. Porque cuando llegábamos aquí con ellos, nuestros padres nos hacían devolverlos.

AL: Para preguntar a dónde los habían encontrado ustedes.

EP: Para preguntar a dónde habíamos ido a cortar esos plátanos. Entonces teníamos que llevarlos por allá, a botarlos por allá, para venir sin nada.

\footnotetext{
${ }^{68}$ Propia de las shame cultures o culturas de la vergüenza, bien distintas de las guilt cultures o culturas de la culpa interiorizada.

${ }^{69}$ Palabra griega que designa la educación de niños y jóvenes para hacer de ellos ciudadanos íntegros de la polis.
} 
AL: Sí, porque entonces tenían que hablar los padres de esos, tenían que decir que era robado. Y como era robado, entonces los padres tenían que saber si era robado o si era en el río.

EP: O regalado.

AL: O regalado. Por eso sus padres les hacían devolver.

(Padilla Ortega "Kaná” y Herrera Torres)

En este universo ético, era preferible recibir un castigo siendo inocente que quedar impune siendo culpable. ${ }^{70}$

EP: Otra cosa. Cuando veníamos azotados por la gente vieja de antes, no podíamos hablar ahí frente a nuestros padres. Frente a nuestros padres no reportábamos: -¡que el tipo me pegó! Porque nos preguntaban:-¡Bueno! ¿Qué le hiciste? Ven acá, que tú tienes que decirme ¿qué fue lo que hiciste, que él te pegó? Entonces, por el miedo, no podíamos decir nada. Porque entonces teníamos que cargar con otra paliza ahí en casa otra vez. ¿Entiendes?

YM: Entiendo.

AL: ¡Fuerte la paliza que ellos les iban a dar!

(Padilla Ortega "Kaná” y Herrera Torres)

Por otra parte, los interlocutores muestran un cierto orgullo de la elementalidad de los orígenes, así como de la homogeneidad racial y lingüística de la comunidad palenquera en el pasado:

JR: No había iglesia. No había nada de eso. Entonces los santos estaban en una casa por allá. Una casa que decían ser de la tía Gregoria. Y eso estaba aquí y era puro monte. Hasta ahora que ustedes, la gente del lado de afuera, vinieran. Ya está modificándose Palenque, porque aquí no había blancos. Aquí todos eran con cabello negro, todo negrito, todos. Porque aquí no había nada de eso.

EP: Cabello crespo.

JR: Cabello crespo. Entonces todo el mundo aquí, los nombres aquí, todo el mundo decía los nombres: Santico era Chó Santico, era Chó, Chó Santico, como Chó Chivo, Chá Chingo, Chá Cato...

70 Moñino comenta al respecto: "En Palenque, como en África, la culpa no es individual, sino diluida en lo colectivo: quién la carga es la familia, el barrio, la comunidad. El individuo que atrae la vergüenza sobre el grupo por un comportamiento inadecuado y afecta así al buen renombre del grupo, ese individuo no importa quién es. En las culturas de la vergüenza, la culpa es compartida por todos. La paideia entra en las mentes con palizas, o mejor dicho con el temor a la paliza: uno aprende el comportamiento deseable no porque interiorizó la culpa de haber cometido el mal (saben que sus padres hicieron las mismas maldades de niños, los padres se las contaban), sino por temor, por puro miedo a la paliza. En África y en Palenque, no hay interiorización de la culpa por el individuo aislado" (c.p. 25 de agosto de 2012. Cfr. Ortigues).

$111 \frac{\text { Revista Iberoamericana, Vol. LXXXII, Núms. 255-256, Abril-Septiembre 2016, 507-549 }}{\text { ISSN 0034-9631 (Impreso) }}$ 
EP: Chá Cato, Chá Chingo, Chá Cuche...

JR: Chá Cato. Aquí todo era por Chó, no era más que Chó. Esa es \{la\} lengua más grande de Palenque. Esa es \{la\} lengua más grande que Palenque tiene, porque todo ahora es que llegó la educación escolar. Ya pusieron a la gente dizque a hablar en castellano.

(Reyes Cáceres y Padilla Ortega "Kaná”)

Aún la topografía, la flora y la fauna se han degradado en los tiempos actuales: ${ }^{71}$

JT: En el sitio de Ñapa, agarré una hicotea. Allá donde está Ñapa, hoy parece que no hubiera habido arroyo ahí.

RM: Observa como está eso. \{Eso está vuelto no se sabe ni qué.\} Todo eso se acabó.

JT: ¿Se acabó! Todas las cosas. Todas las cosas que teníamos en una época, todas las cosas se acabaron.

RM: ¿Se acabaron! Hasta la gente se está acabando y las cosas no se van a acabar.

JT: ¡Mire usted! En Chó Pacho había... No sé de dónde venían esas bocachicos, había bastantes bocachicos en Chó Pacho.

RM: ¡Eeh! Barbudos y arencas.

JT: ¿Y de dónde es que venían?

RM: Había también para coger ahí, \{ve.\} En Chó Pacho.

JT: $\quad$ Ahí en el pozo de Vicenta Pérez, había una poza grande.

RM: ¡Ahí, ahí! Esa poza estaba profunda.

JT: $\quad$ Mira, y todo eso se acabó.

RM: Y todo eso se ha vuelto \{no se sabe ni qué.\} Ellos mismos fueron quienes echaron todas esas cosas a perder.

JT: $\quad$ Mire, $\{$ le digo que $\}$ ahí en Casinguisito, en Casinguisito...

RM: Eh, así es.

JT: $\quad$... ahí había unas pozas, ahí está la poza Nicolo.

RM: ¡Sí señor! Yo tengo como treinta años sin no ir por allá, por la poza Nicolo.

JT: Tú no vas más por allá, por donde todas esas pozas se acabaron.

RM: Todas esas pozas se acabaron. Han pasado como cuarenta años desde que iba por allá. Éramos señoritas, nadando en esa poza.

(Torres Valdez y Miranda Valdez)

La modernidad no ha dejado nada fuera de su influencia: aún el baile, destreza tradicional del palenquero y parte del saber-hacer ritual, se ha contagiado de modas foráneas y está perdiendo su cualidad distintiva y religiosamente marcada:

${ }^{71}$ Los alrededores de Palenque han cambiado drásticamente. Los palenqueros son concientes de que, debido a la deforestación, las condiciones ambientales han empeorado mucho: sin las raíces que retenían el agua, los arroyos, las grandes ciénagas, las pozas y las zonas inundables han ido desapareciendo durante los últimos cincuenta años, y siguen desapareciendo. Y no hablemos de la fauna... (Moñino, c.p. 26 de agosto 2012). 
EP: Ahora, los jóvenes de ahora, no son como nosotros antes. Los jóvenes de mi edad, de mi cuadrilla, todos bailamos toda clase de música. Bailamos música champeta de África, bailamos vallenato, bailamos... Bailamos salsa, puertorriqueño, panameño, bailamos... Tú sabes que antes la gente decía que la música romántica era el bolero, lo sabes, ¿no, verdad?

AL: Él sabe que las fiestas de antaño eran bolero.

EP: $\quad$ Y todo eso, lo bailábamos extraordinariamente bonito. Y los jóvenes de ahora no saben bailarlo. Ninguno de ellos sabe bailarlo.

(Padilla Ortega "Kaná” y Herrera Torres)

En la conversación de Inés Ortega Cassiani y Raúl Salas Hernández encontramos un delicioso ejemplo de aquella retórica de la facticidad de la que hablara Van Dijk en relación con los recursos a las cifras del periodismo. ${ }^{72}$ En efecto, en este diálogo irrumpe un bombardeo de cronónimos para indicar la avanzada edad de los interlocutores y de sus vecinos, así como sus respectivos natalicios, lo que pone de manifiesto el valor que se otorga a la memoria en cifras dentro de estas sociedades orales, escasas en soportes escritos:

IO: Tú sabes, yo tengo ochenta y nueve años.

CO: $\quad\{$ iOchenta y nueve, uau!\}

RS: \{Nació en el 1914. ¿Cuántos años hacen?\}

CO: $\quad$ Ochenta y nueve.\}

RS: $\quad$ Hay una señora en San Cayetano que nació en 1912. ¿Cuántos años hace?\}

CO: $\quad$ Y la mamá de Yves tiene noventa y seis.\}

RS: $\quad$ No la conocí. $\}$

YM: $\quad$ Ella nació en el 1905.\}

RS: \{Ella era cuagrilla con "Kuña”, con el viejo Fermín, el papá de Yayita, era con... Vea, yo conocí una china que nació en el 1816.\}

CO: $\{; U y !\}$

BP: $\{$ En Turbaco, hay una que el año pasado...

CO: $\quad$ ¿En 1816? ¡Imposible! En el 1896.\}

BP: $\quad$ OOiga, mi abuelo viejo Anselmo, era de 1894.\}

IO: ¿Tu abuelo? Él los tenía, verdad.

RS: $\quad\{$ Mi abuelo era...

BP: \{Y duró como sesenta... como treinta años aciego. Yo nunca lo conocí bién.

CO: $\{¡ U y !\}$

RS: \{Ah, yo sí lo conocí bién. Ah, yo le voy a decir una cosa: el abuelo mío nació en el 1898.\}

BP: $\quad$ En Turbaco hay una señora que el año pasado, que el año pasado tenía ciento diez y nueve años, y todavía estaba ensartadando agujas y se partió fue esto, un brazo, porque fue a corretear un chisme. El año pasado.\}

${ }^{72}$ Para reforzar el pacto narrativo de veracidad en las noticias (La ciencia del texto).

$111 \frac{\text { Revista Iberoamericana, Vol. LXXXII, Núms. 255-256, Abril-Septiembre 2016, } 507-549}{\text { ISSN 2154-4794 (Electrónico) }}$ 


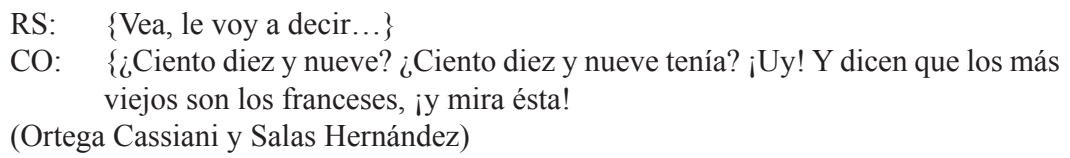

Así, lejos de ocultarse o rebajarse ${ }^{73}$-como ocurre en las conversaciones sociales de la modernidad urbana- la edad avanzada es motivo de orgullo en Palenque.

\section{LUMBALÚ}

El género más estudiado dentro de la oralitura palenquera son los lumbalúes. Ocupan un lugar único, dado su carácter sagrado, su performance ritual y su génesis antigua. Durante mucho tiempo se creyó que se trataba de cantos inefables aún para los mismos palenqueros, pero cuando el discurso científico comenzó a decodificarlos, descubrió que -fuera de las palabras arcanas de origen africano-importante parte de su lengua era conocida para los palenqueros y aparecía intercalada con el español en forma de code switching o cambio de código (Schwegler, "Chi ma nkongo" 6-7). En efecto, los lumbalúes constituyen un ejemplo del continuum creole ${ }^{74}$ caribeño, fenómeno asociado a la noción de cross-culturalidad ${ }^{75}$ que designa procesos de descomposición y recomposición lingüística y cultural en las sociedades poscoloniales.

La forma composicional del lumbalú es formularia, fragmentaria y cuenta con un mínimo desarrollo narrativo-argumentativo: los efectos de sentido se gestan en el nivel de la alusión y el símbolo; la palabra, liberada de la prisión sintáctica, navega en un mar de connotaciones semánticas cuyo eco se pierde en antiguas rutas de estos Pueblos del mar. La significación del lumbalú se completa realmente en la performance, en la que se pueden apreciar los elementos suprasegmentales (entonación e íctus) así como los elementos dramáticos (proxemia y kinesia). El lumbalú 'Katalina Luango' (Schwegler, "Chi ma nkongo" 178-283), por ejemplo, arranca con un ritornello de sílabas expresivas ${ }^{76}$-genéticamente asociadas a la función emotiva o expresiva del lenguaje $-{ }^{77}$ cuya funcionalidad es incrustar en el sintagma verbal una coloración tímica disfórica, manifestación verbal del dolor:

73 Incluso desterrarse de las conversaciones sociales, según el decoro de los "manuales de urbanidad".

74 El continuum creole es un fenómeno frecuente en el language game (Lyotard; Benítez) caribeño y consiste en el movimiento pendular de las actuaciones lingüísticas criollas, entre la tradición y la innovación.

75 Este concepto vendría a reemplazar las concepciones más tradicionales de mestizaje, multiculturalismo y melting pot (Glissant).

76 En palenquero esta figura cantada se llama leko 'llanto'. Se encuentran tal cual en los cantos funerarios koongo (Moñino, c.p., 29 de agosto 2012). Schwegler los llama : “elementos expresivos” (1996, 62-63).

77 Cuya fuente es el emisor del mensaje, es decir, el “yo” de la enunciación (Jakobson, Ensayos). 
$\{\tilde{N} a$ María Catalina, (de) Luango\}, e, chimbumbe e,

olelelelo, elilelelilelo, ${ }^{78}$ kaposanto;

e, chimbumba negra Luango, e, chimbumbe, olelelelo, elilelelilelo, kaposanto;

é kanoa a koe río Lamb', e; María Luango;

olelelelo, elilelelilelo, kaposanto.
\{Doña María Catalina de Luango\}, eh, chimbumbe e, olelelelo, elilelelilelo, cementerio; eh, chimbumba negra de Loango, eh, olelelelo, elilelelilelo, cementerio;

eh, la canoa cogió por el río Lamba, eh; María Loango; olelelelo, elilelelilelo, cementerio; (Schwegler 178-79)

La figura de Katalina Luango está asociada tradicionalmente a la isotopía de las aguas - conectada al simbolismo tanático primordial-y visible aquí en diversas marcas léxicas, como/ciénaga/,/canoa/,/río/-. ${ }^{79}$ Del mismo modo, en el lumbalú "Chimbumbe" aparece la figura anfibia de Katalina, asociada a la palabra chimbumbe ${ }^{80}$-ver más arriba-.

\author{
Oo ña María Catalina Luango e Chimbumbe \\ Ooo elée lelóo \\ Oo ya ta tragá ri chimbumbe ata la mitá \\ Oo elée chimbumbe ee \\ Oo ya ta tragá ri chimbumbe \\ Ooo ya ta tragá ata la mitá \\ Oo María Catalina Luango. \\ (Escalante 81-82, adaptación Moñino)
}

Oo doña María Catalina Loango e, moján

ya está tragada por el moján hasta la mitad

Por otra parte, en ambos lumbalúes aparece actualizada la simbología negativa de las aguas oscuras, el mare tenebrum (Durand 89; Bachelard). Esta ofelización ${ }^{81}$ de las aguas constituye una invitación a la muerte: "el agua que corre es amarga invitación al viaje sin retorno $[\ldots]$ es epifanía de la desgracia del tiempo, es clepsidra definitiva" (Durand 90).

78 La negrilla es mía.

79 La imagen de la canoa está aquí asociada al ataúd, pero podría conectar con una imagen muy difundida en las catábasis de la tradición occidental: la figura de Caronte, barquero infernal que lleva las almas al más allá por las aguas del río Aqueronte.

80 "Chimbumbe" es un término opaco, objeto de varias interpretaciones entre los mismos palenqueros: 'moján, retorno, muerte' (Moñino, c.p., 29 de agosto 2012). La glossolalia (el "hablar muchas lenguas”) es un recurso estructural del lumbalú, utilizado dentro del proyecto estético del negrismo en el temprano siglo XX. Los poemarios Motivos de son (1930) y Sóngoro cosongo (1931) del joven Guillén, constituyen un célebre ejemplo de la llamada "economía política del ritual” (Benítez Rojo), dado que la presencia de palabras intraducibles en el poema escrito en lengua española, es ella misma ritual y, a la vez, apoya el proyecto sociorracial de las afrorreclamaciones en Cuba (Maglia, De la machina).

81 Referencia a la Ofelia de Shakespeare. 
La invocación de los nombres en el lumbalú constituye un acto ilocutorio, un decir y un hacer a la vez, dado que en el apóstrofe se invoca la presencia casi con operatividad mágica. En el breve texto de Juan Gungú, "lumbalú más recordado aún existente" (Schwegler, "Chi ma nkongo" 525), se destaca el lugar de enunciación en primera persona yuxtapuesto a la mención de los ancestros asociados a topónimos y gentilicios africanos, lo que conforma un verdadero epíteto genealógico al estilo del lenguaje formulario de la épica: ${ }^{82}$ esta forma de definir la identidad es propia de las sociedades tradicionales, que prestigian el presente en la conexión con los antepasados que vivieron in illo tempore, ab initium: ${ }^{83}$

Chi ma nkongo

Chi ma nluango

Chi ma ri Luango de Angola

Juan Gungú me ñamo yo

Juan Gungú me a re ñamá

Cuando só ta kai, mam'é.

(Escalante 79)
Soy de los congo.

Soy de los loango.

Soy de los de Loango de Angola.

Juan Gungú me llamo yo.

Juan Gungu me ha de llamar.

Cuando el sol se cae [para] su mamá.

Paralelamente a los lumbalúes endogámicos en donde aparece la onomástica del clan:

arió!, tokaba tambolero ño Perito Sargao, eleleo;

kanto tokaba Osé Transitoria Ávila,

tambolero Kammero, oelelelo;

ese Patonito ku chá Karaka, \{la tierra Boliva\}, elele;

i Kiko Juana Bákoa,

(Katalina Loango)

(Schwegler, "Chi ma nkongo" 178-79) ¡adiós!,tocabael tamborerodonPeritoSalgado, eleleo;

el canto [lo] tocaba José [hijo de] Transitoria Ávila;

el tamborero Carmelo, oelelelo;

ese Patronito y Tía Caracas \{de la tierra de

Bolívar\};

y Quici [hijo de] Juana Bácoa,

encontramos composiciones más recientes, a veces llamadas pseudolumbalúes o neolumbalúes (Schwegler, “Chi ma nkongo” 630), en donde aparecen figuras exogámicas,

${ }^{82}$ En la épica homérica: el peleíade Aquiles (Aquiles, hijo de Peleo) o Ayante telamonio (Ayax, hijo de Telamón).

${ }^{83}$ El sistema palenquero tradicional de identificación es matrilineal, como el congolés (donde una persona, así sea el Rey, hereda el apellido clánico y los bienes de su tío materno, no de su padre). Claro que son sociedades patriarcales (el poder está siempre en mano de los hombres, de los padres en un sistema patrilineal, de los tíos maternos en uno matrilineal). De ahí la importancia del apelativo 'Tío' o Chó con todo el respeto y la sumisión asociados a él en Palenque, cuando tatá 'papá' es puramente afectivo. Filiación y poder son dos cosas diferentes (Moñino, c.p., 30 de agosto 2012). 
como Nina de Friedemann y Carlos Patiño Rosselli, científicos colombianos pioneros en el "descubrimiento" de Palenque en las décadas de los setenta-ochenta:

(11) Nina á kojé Palenge mucho amó é.

Nina le ha tomado mucho amor a Palenque.

(12) É pok'él'á tré mon'ele pa kunosé Palenge é.

Es porque ella trajo a su hija a conocer a Palenque.

(13) Palenge á ngutalo batante é.

Palenque le ha gustado bastante.

(14) I e dottó Patiño á mini a kunosé Palenge é.

$\mathrm{Y}$ el doctor Patiño vino a conocer Palenque.

(15) Él'á miní ku Nina.

Él vino con Nina.

(16) E yenno Maria Konse á miní a kunoselo.

El yerno de María Concepción vino a conocerlo.

(17) Nina tá besando é.

Nina la está besando.

(18) Arió, Nina, i Bogotá.

Adiós, Nina, de Bogotá.

(19) Tanto boluntá Nina tené aki Palenge é ke á tré dottó Patiño ku mon'ele pa miní a kunosé Palenge.

Tanto cariño le tiene Nina a Palenque que trajo al Dr. Patiño con su hija para venir a conocer Palenque.

(20) Tó ané tán morí aki Palenge.

Todos ellos morirán aquí en Palenque.

(21) Nina tán morí aki Palenge p'uto kandalo baile mueto.

Nina morirá aquí en Palenque para nosotros cantarle el baile de muerto.

(22) Arió, Nina, arió.

Adiós, Nina, adiós.

(23) E dottó Patiño kuándo é ke muere aki Palenge, p’uto kandalo baile mueto.

El doctor Patiño ¿cuándo es que morirá aquí en Palenque, para cantarle

el baile de muerto?

(Lumbalú I) (Patiño cit. en Friedmann y Patiño Roselli 260-61; adaptación de Moñino) 
A pesar de su antigüedad y su lenguaje formulario, el lumbalú es un género flexible, que tiene la capacidad de enfrentarse a nuevas circunstancias históricas, como en este caso en que se registra la "adopción afectiva" de estos dos científicos colombianos que llegaron a Palenque. Al respecto, afirma Moñino:

el lumbalú, a la vez de ser la expresión del dolor frente a la muerte, es también una alabanza a los muertos que se puede extender a los que van a morir un día. A los vivos venidos de afuera, se les expresa la voluntad de incluirlos en la comunidad: morirán en Palenque, dicen esos nuevos lumbalúes. Lo veo como la adaptación de un modelo tradicional (en el Congo es general esta función de alabanza a los vivos, asociada a los ritos funerarios) a situaciones inéditas como la llegada de etnólogos o linguistas. (c.p., 30 de agosto 2012)

\section{CONCLUSIONES}

Yves Moñino señala que "Menos de una quinta parte de los palenqueros hablan la lengua, más de la mitad tiene de ella un conocimiento pasivo y un cuarto ni la entiende. Para resumir la situación sociolingüística actual de la comunidad palenquera: la diglosia generalizada de antaño está siendo sustituida por el monolingüísmo en español" (Maglia y Moñino 26). En contra del deseo de muchos y a pesar de la revitalización del interés por la lengua luego de la patrimonialización global y la implementación de los planes de etnoeducación, podríamos decir que la lengua está en un progresivo proceso de pérdida como código de comunicación cotidiana. ${ }^{84}$ En la experiencia de una modernidad periférica, en tiempos en que la modernización tecnológica va de la mano de las memorias rotas (Díaz Quiñones), más que nunca, es casi un deber dejar una memoria escrita de este invaluable patrimonio oral que representa la oralitura y la oratura palenquera. La escritura otorga estatuto literario a las prácticas discursivas palenqueras de manera que tiene lugar un proceso de doble ganancia (win-win game): por una parte, el archivo letrado se enriquece con el aporte de la lengua cruda, incontaminada y anómica de la performance oral y, por otra, la oralidad entra en una red lingüística y sociocultural más amplia que la multiplica de manera geométrica.

Por su parte, el análisis etnolingüístico y sociosemiótico permite mirar el mundo analizado en su agenciamiento, como un lugar y un acto de enunciación más que como un corpus de enunciados bajo la lupa del investigador, poniéndonos a salvo de la consabida reificación del objeto de investigación, especialmente grave en el caso del trabajo con

\footnotetext{
${ }^{84}$ Carlos Patiño Rosselli predijo hace treinta años: “¿Qué quedará del criollo en la próxima generación? Salvo la intervención de factores improbables aunque no imposibles [...], la finalización del ciclo histórico del lenguaje palenquero no parece estar muy lejos" (Patiño cit. en Friedmann y Patiño Rosselli 191).
} 
comunidades vivas (Duchesne). Nuestra intención, entonces, es dialogar desde dentro de la textualidad cultural, en un intercambio poroso con la tradición heterogénea y retornar a la comunidad esta lectura horizontal, posible gracias a su propia capacidad y energía, que nosotros aprovechamos en la tarea de salvarla del olvido.

En el análisis de la oralitura palenquera nos enfrentamos a las dificultades propias del análisis literario, sumadas a las condiciones sui generis de la literatura oral de una comunidad afrocriolla con diglosia. Este peculiar escenario lingüístico y cultural actúa como catalizador de fenómenos como el code switching, la variación lingüística, la reinvención de la memoria y la performance identitaria, poderosos factores que registran la diferencia cultural, promueven la creolización y piden al investigador categorías e instrumentos de análisis interdisciplinarios. Por otra parte, cuando el lenguaje abandona la función instrumental que le impone cotidianamente el código gregario, y entra en los cauces de la poíesis verbal, intensifica la polisemia a través de la creación de espacios interlectales en donde irrumpen nuevos significados. Nuestro corpus presenta, además, una fuerte dimensión dialógica que dinamiza el flujo comunicativo y dispone casi en una mise en abyme muchos de los textos recabados.

En medio de la corriente de conciencia (stream of consciousness) que promueve la oralidad, hemos constatado un deslizamiento entre los distintos géneros que refuncionaliza el canon literario y crea verdaderas obras abiertas (Eco). Sin duda, hay géneros altamente codificados, como las coplas y décimas, que se acogen a unas precisiones prosódicas, así como los dichos y refranes y el lumbalú que tienen un molde sintáctico fijado por la tradición; y otros menos codificados, como las historias de vida, la conversación y el diálogo, que cuentan con una gran dosis de creación individual, fuertemente hibridada por la presencia del texto cultural y el sujeto cultural (Cros), de procedencia colectiva y actualizados por el orador.

La tradición oral constituye un punto axial de la resistencia cultural de los grupos afrodiaspóricos: la memoria ancestral tiene una faz ritual y una lingüística. La reactualización del mito y el rito contrarrestan la erosión identitaria que producía el régimen esclavista y permiten una salida a la situación de ambivalencia colonial (Bhabha). La estrecha relación entre lenguaje e identidad se intensifica en los textos poscoloniales y se puede analizar en el marco del continuum creole, movimiento pendular del habla local que juega alternativamente entre el rechazo y la adhesión a la norma oficial en un extremo, y en el otro a la lengua comunitaria. La construcción de las identidades creolizadas como las de Palenque convoca tradiciones supersincréticas (en este caso de Africa, Europa y América) y pone al investigador frente al desafío de decodificarlas. El texto oral es, pues, un sitio privilegiado para remontarnos a través del trabajo mnemotrópico de la oralidad hacia los puntos cardinales de la visión de mundo comunitaria. Cifrados tras la metáfora poética, la metonimia narrativa o la prosopopeya de la fábula, los valores colectivos se perpetúan de generación en generación y vienen a inscribirse sincrónicamente en el campo literario nacional, afrocaribe y afrodiaspórico.

$111 \frac{\text { Revista Iberoamericana, Vol. LXXXII, Núms. 255-256, Abril-Septiembre 2016, } 507-549}{\text { ISSSN 2154-4794 (Electrónico) }}$ 


\section{BiBLIOGRAFÍA}

Aarne, Antti. The Types of the Folktale: A Classification and Bibliography. Stith Thompson, trad. Helsinki: Suomalainen Tiedeakatemia/FF Communications, 1961.

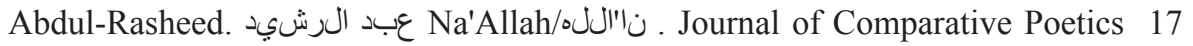
(1997): 125-42.

Adorno, Theodor. "Sobre la poesía tardía de Hölderlin". Notas sobre Literatura. Obras Completas Vol. II. Madrid: Ediciones Akal, S.A., 2003.

Arrázola, R. Palenque, primer pueblo libre de América: historia de las sublevaciones de los esclavos de Cartagena. Cartagena: Hernández, 1970.

Arroyo, Jossianna. Travestismos culturales: literatura y etnografia en Cuba y Brasil. Pittsburgh: Instituto Internacional de Literatura Iberoamericana, 2003.

Ashcroft, B., G. Griffiths y H. Tiffin. The Empire Writes Back. Londres/New York: Routledge, 1989.

Bachelard, G. El agua y los sueños. México: F.C.E., 2003.

Bachtín, M. "El problema del contenido, el material y la forma en la creación literaria". Teoría y estética de la novela. Madrid: Taurus. 1989.

Barthes, R. S/Z. Oxford: Blackwell, 1975.

Image, Music, Text. Nueva York: Noonday, 1977.

El placer del texto y Lección Inaugural de la Cátedra de Semiología Literaria del College de France. México: Editorial Siglo XXI, 1989.

Bateson, G. Steps to an Ecology of Mind. New York: Ballantines Books, 1976.

Benítez Rojo, Antonio. The Repeating Island: The Caribbean and the Postmodern Perspective. Durham / Londres: Duke University Press, 2001.

Benjamin, Walter. "The Storyteller. Reflections on the Work of Nikolai Leskov". Illuminations. Essays and Reflections. H. Arendt, ed. Nueva York: Shocken Books, 1969. 83-110.

Beutler, Gisela. Estudios sobre el romancero español en Colombia: En su tradición escrita y oral desde la época de la conquista hasta la actualidad. Bogotá: Instituto Caro y Cuervo, 1977.

Beverley, John. “Anatomía del testimonio”. Revista de Crítica Literaria Latinoamericana 25 (1987): 7-16.

Bhabha, H. El lugar de la cultura. Buenos Aires: Manantial, 2002.

Bickerton, D. y A. Escalante. "Palenquero: a Spanish-based creole of Northern Colombia”. Lingua 24 (1970): 254-267.

Bonfil Batalla, G. "La teoría del control cultural en el estudio de procesos étnicos". Papeles de la Casa Chata 2.3 (1987): 23-43.

Bourdieu, P. Las reglas del arte. Barcelona: Anagrama, 1997.

Brioschi F. y C. Di Girolamo. Introducción al estudio de la literatura. Barcelona: Ariel, 2006.

$111 \frac{\text { Revista Iberoamericana, Vol. LXXXII, Núms. 255-256, Abril-Septiembre 2016, } 507-549}{\text { ISSN 2154-4794 (Electrónico) }}$ 
Campbell, J. El héroe de las mil caras. Psicoanálisis del mito. México: F.C.E., 1959. Cañate Cáceres "Sikito", Francisco. Agua tán yobé. Grabado por Yves Moñino. Archivo

Moñino. 2012. El chocho. Grabado por Yves Moñino. Archivo Moñino. 2012. Obsequio en verso. Grabado por Yves Moñino. Archivo Moñino. 2012. Palo por palo son palos. Grabado por Yves Moñino. Archivo Moñino. 2012. Quiero besar tu cabello. Grabado por Yves Moñino. Archivo Moñino. 2012. y Dionisio Miranda. Segunda conversación. Grabada y traducida por Yves Moñino. Archivo Moñino. 2002.

Cásseres Estrada, S. Diccionario de la lengua afropalenquera-español. Cartagena: Ediciones Pluma de Mompox, 2005.

Charaudeau, P. y D. Maingueneau. Diccionario de análisis del discurso. Buenos Aires: Amorrortu, 2005.

Chaudenson, R. Des îles, des hommes, des langues. París: l'Harmattan, 1992.

Clifford, J. "On Ethnographic Authority." Writing Culture: The Poetics and Politics of Ethnography. J. Clifford y G. Marcus, eds. Berkeley: California UP, 1986. 1-26. Cornejo Polar, Antonio. Escribir en el aire. Ensayo sobre la heterogeneidad sociocultural en las literaturas andinas. Lima: Editorial Horizonte, 1994.

Cros, Edmund. El sujeto cultural. Sociocrítica y psicoanálisis. Buenos Aires: Corregidor, 1997.

Dash, M. "Psychology, Creolization, and Hybridization." New National and Postcolonial Literatures. An Introduction. Oxford: Clarendon Press, 1996.

Díaz Quiñones, A. La memoria rota. Río Piedras: Ediciones El Huracán, 1996.

Duchesne, Juan. "Miguel Barnet y el testimonio como humanismo". Revista de Crítica Literaria Latinoamericana 26 (1987): 155-60.

Ducrot, O. \& T. Todorov. Diccionario enciclopédico de las ciencias del lenguaje. México: Siglo XXI Editores, 1980.

Durand, G. Estructuras antropológicas de lo imaginario. Madrid: Taurus, 1982.

Eco, Umberto. Obra abierta. Barcelon: Planeta, 1992.

Escalante, A. Notas sobre el Palenque de San Basilio, una comunidad negra de Colombia. Barranquilla: Universidad del Atlántico, 1954.

Fall, Y. "Historiografía, sociedades y conciencia histórica en África". África inventando el futuro. México: El Colegio de México, 1992.

Fichte, H. Etnopoesía. São Paulo: Editora Brasiliense, 1987.

Di Filippo, M. Alario. Lexicón de colombianismos. Cartagena: Editorial Bolívar, 1964. Foucault, Michel. La arqueología del saber. Buenos Aires: Siglo XXI, 2002.

Freud, Sigmund. Jokes and their Relation to the Unconscious. 1905. Harmondsworth: Penguin, 1991.

$111 \frac{\text { Revista Iberoamericana, Vol. LXXXII, Núms. 255-256, Abril-Septiembre 2016, 507-549 }}{\text { ISSN 0034-9631 (Impreso) }}$ 
Freja De La Hoz, A. F. "Romances, coplas y décimas en el Pacífico y el Caribe colombiano: poética de una literatura oral en Colombia". Tesis de maestría, Universidad Nacional de Colombia, 2012.

Friedemann, N. "En terrenos de la diáspora afrocolombiana. Cosmovisiones e imaginarios". Estudios de literatura y cultura colombianas y de lingüistica afrohispánica. P. Konder, M. Perl y K. Pörtl, eds. Frankfurt am Main: Peter Lang, 1995. 75-88.

y C. Patiño Rosselli. Lengua y sociedad en El Palenque de San Basilio. Bogotá: Instituto Caro y Cuervo, 1983.

García Canclini, Néstor. Culturas Hibridas. Estrategias para entrar y salir de la modernidad. México: Grijalbo, 1999.

Gilroy, P. Black Atlantic: Modernity and Double Consciousness. Cambridge: Harvard UP, 1992.

Glissant, E. Caribbean Discourse. Selected Essais. Charlottesville: UP of Virginia, 1999.

Goffman, E. Forms of Talk. Philadelphia: U of Pennsylvania P, 1981.

Interaction Ritual: Essays on Face-to-Face Behavior. Garden City (NY): Doubleday Anchor Books, 1967.

González Echevarría, R. "Guillén as Baroque: Meaning in Motivos de Son”. Callaloo 31 (1987): 302-17.

Görög, V. y Ch. Seydou. La fille difficile: un conte-type africain. París: CNRS, 2001. Granda, G. de. Estudios sobre un área dialectal hispanoamericana de población negra. Las tierras bajas occidentales de Colombia. Bogotá: Publicaciones del Instituto Caro y Cuervo, 1977.

"La tipología 'criolla' de dos hablas del área lingüística hispánica". Thesaurus 23 (1968): 193-205.

Greimas, A. Ensayos de semiótica poética. Barcelona: Planeta, 1976.

y J. Courtes. Semiótica. Diccionario razonado de la teoría del lenguaje. Madrid: Gredos, 1990.

Gumperz, J. Discourse Strategies. Cambridge: Cambridge UP, 1982.

Engager la Conversation. París: Les Editions de Minuit, 1989.

"Introducción". Directions in Sociolinguistics. The Ethnography of Communication. J. Gumperz y D. Hymes, ed. New York: Holt, Rinehart and Winston, 1972.

Haensch G. y R. Werner. Nuevo diccionario de colombianismos. Bogotá: Instituto Caro y Cuervo, 1993.

Hagège, C. L'homme de paroles. París: Odile Jacob, 1985.

Hall, S. y P. Du Gay. Cuestiones de identidad cultural. Buenos Aires/Madrid:Amorrortu, 2003.

Jung, Carl. Obra completa. Vol. 9/I. Madrid: Editorial Trotta, 2002.

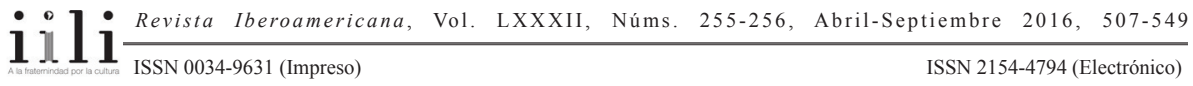


Knowles-Borisha, Adetokunbo F. "Paradigm for Classical African Orature: Instrument for a Scientific Revolution?” Journal of Black Studies 21/4 (1991): 488-500.

Krupat, A. Ethnocriticism. Ethnography, History, Literature. Berkeley: U of California P, 1992.

Jakobson, R. Ensayos de lingüística general. Barcelona: Seix Barral, 1975.

Labov, W. Language in the Inner City: Studies in the Black English Vernacular. Philadelphia: U of Pennsylvania P, 1972.

Lang, A. The Blue Fairy Book. Dover Publications, 1965.

Lapesa. R. "El mundo de la antigua lírica popular hispánica". Saber Leer 19(1988): 4-5.

Lida de Malkiel, M. R. El cuento popular y otros ensayos. Buenos Aires: Losada, 1976.

Lienhard, M. La voz y su huella. Lima: Editorial Horizonte, 1992.

Lipski, J. A History of Afro-Hispanic language. Cambridge: Cambridge UP, 2005.

Lotman, I. Estructura del texto artístico. Madrid: Istmo, 1978.

Losada, A. "Los sistemas literarios como instituciones sociales". Revista de Crítica Literaria Latinoamericana 1 (1975): 39-60.

Lyotard, J.F. La condición posmoderna. Madrid: Cátedra, 1987.

Maglia, G. De la machina imperial a la vereda tropical. Poesía, identidad y nación en el Caribe Afrohispánico. Bogotá: Editorial Javeriana, 2009.

eY.Moñino. Kondalo pa bibímejó. Contarlopara vivirmejor: Oraturayoralitura de San Basilio de Palenque, Colombia. Bogotá: Editorial Javeriana / ICC, 2015. y A. Schwegler, eds. Palenque (Colombia): oralidad, identidad y resistencia. Bogotá: Instituto Caro y Cuervo y Universidad Javeriana, 2012.

Martín Barbero, J. De los medios a las mediaciones. México: Gustavo Gili, 1987.

Mc Luhan, M. The Gutenberg Galaxy: The Making of Typographic Man. Routledge y Kegan Paul, 1962.

Understanding Media: The Extensions of Man. Berkeley: Gingko Press, 1964.

Megenney, W. El palenquero. Un lenguaje post-criollo de Colombia. Bogotá: Instituto Caro y Cuervo, Biblioteca Lxxiv, 1986.

MenéndezPidal, R. "Poesía popular y poesía tradicional en la poesía española”. Estudios sobre el Romancero. Madrid: Espasa-Calpe, 1973. 325-356.

Mignolo, Walter. Historias locales/diseños globales. Colonialidad, conocimientos subalternos y pensamiento fronterizo. Madrid: Ediciones Akal, 2002.

Miranda Hernández, Julia. Tía Zorra y tío Conejo. Grabado por Alejandro Correa. Archivo Maglia, 2009.

Moñino, Y. "El sistema modo-aspectual del verbo en palenquero: una semántica gramatical africana". Lenguas aborígenes de Colombia. Memorias 6: Congreso de lingüistica amerindia y criolla. Bogotá: CCELA / Universidad de los Andes, 2001. 147-160. 
"Las construcciones de genitivo en palenquero: ¿una semantaxis africana?". Palenque, Cartagena y Afro-Caribe. Historia y lengua. Y. Moñino y Schwegler, eds. Tübingen: Niemeyer, 2002. 227-48.

"Lengua e identidad afroamericana: el caso del criollo de Palenque de San Basilio (Colombia)". Caminos cruzados. C. Alès y J. Chiappino, eds. París-Caracas: IRDÉditions / ULA-Grial, 2003. 517-31.

"Convergencias lingüísticas iberocongolesas en palenquero: ¿integrarse a la sociedad mayoritaria o distinguirse de ella?" Lenguas en contacto en el Caribe y más allá. M. Sokol y W. Mihatsch, eds. Frankfurt: Peter Lang, 2007. 37-59.

"Pasado, presente y futuro de la lengua de Palenque". Palenque (Colombia): oralidad, identidad y resistencia. Maglia y Schwegler, eds. Bogotá: Instituto Caro y Cuervo y Universidad Javeriana, 2012. 179-213.

\& A. Schwegler, eds. Palenque, Cartagena y Afro-Caribe. Historia y lengua. Tübingen: Niemeyer, 2002.

Mukarovsky, I. Escritos de estética y semiótica del arte. Barcelona: Gustavo Gili, 1977. Navarrete, M.C. San Basilio de Palenque: Memoria y tradición. Surgimiento y avatares de las gestas cimarronas en el Caribe colombiano. Cali: Programa Editorial Universidad del Valle, 2008.

Niño, H. "Etnoliteratura, conocimiento y valores". Mopa mopa 4 (1989): 51-75.

"El etnotexto: Voz y actuación la oralidad". Revista de Crítica Literaria Latinoamericana 47 (1998): 109-121.

Okpewho, I. African OralLiterature: Backgrounds, Character, and Continuity. Indiana: Indiana UP, 1992.

Ong, W. J. Orality and Literacy: The Technologizing of the Word. London: Methuen. 1982.

Ortega Cassiani, Inés y Raúl Salas Hernández. Quinta conversación. Grabada y traducida por Yves Moñino. Archivo Moñino, 2002.

Ortigues, Marie-Cécile y Edmond. Edipe africain. París: Plon, 1966.

Pacheco, Carlos. "Sobre la construcción de lo rural y lo oral en la literatura hispanoamericana". Revista de Crítica Literaria Latinoamericana 42 (1995): 57-71.

Padilla Ortega “Kaná”, Encarnación y Alba Luz Herera Torres. Tercera conversación. Grabada y traducida por Yves Moñino. Archivo Moñino, 2002.

Patiño Rosselli, C. "El lenguaje de los afrocolombianos y su estudio". Estudios de literatura y cultura colombianas y de lingüística afro-hispánica. P. Konder, M. Perl y K. Pörtl, eds. Frankfurt am Main: Peter Lang, 1995. 103-34.

Paz, Octavio. El arco y la lira. México: F.C.E., 1986.

Pérez Miranda, B. Chitieno lengua ku ma kuendo. Hablemos palenquero a través del cuento. Cartagena: Ediciones Pluma de Mompox, 2011. 
Petrilli, S. y A. Ponzio. "Storytelling and the Great Narration of Global Communication." Annali della Facoltà di lingue e Letterature straniere. Terza serie/XIV, Fasano: Schena Editore, 2000. 47-61.

Pizarro,A. El archipiélago de fronteras externas. Santiago de Chile: Editorial Universidad de Santiago, 2002.

Posada, C. "Cantos de hoy en el Caribe colombiano". Huellas. Revista de la Universidad del Norte 69-70 (2003): 10-17.

Preminger, A. y T. V. F. Brogan, eds. The New Princeton Enciclopedia of Poetry and Poetics. Princeton: Princeton UP, 1993.

Propp, V. Morphology of the Folk Tale. Bloomington-Austin: Indiana Research Centre of Anthropology/U of Texas P, 1968.

Rama, A. Transculturación narrativa en América Latina. México: Siglo XXI, 1987.

Reyes Cáceres, José y Encarnación Padilla Ortega "Kaná”. Cuarta conversación. Grabada y traducida por Yves Moñino. Archivo Moñino, 2002.

Rincón, C. El cambio en la noción de literatura. Bogotá: Instituto Colombiano de Cultura, 1978.

Schwegler, A. "Chi ma nkongo": lengua y rito ancestrales en El Palenque de San Basilio. Frankfurt: Vervuert, 1996.

"Palenquero". América negra: panorámica actual de los estudios lingüisticos sobre variedades criollas y afrohispanas. M. Perl y A. Schwegler, eds. FrankfurtMadrid: Vervuert/Iberoamericana, 1998. 220-91.

"El vocabulario africano de Palenque (Colombia). Segunda parte: compendio alfabético de palabras (con etimologías)". Palenque, Cartagena y Afro-Caribe. Historia ylengua. Y. Moñino y Schwegler, eds. Tübingen: Niemeyer, 2002. 171-226.

"State of the Discipline. Pidgin and Creole Studies: Their Interface with Hispanic and Lusophone Linguistics". Studies in Hispanic and Lusophone Linguistics 3/2 (2010): 431-81.

"Sobre el origen africano de la lengua criolla de Palenque(Colombia)". Palenque (Colombia): oralidad, identidad y resistencia. Maglia y Schwegler, eds. Bogotá: Instituto Caro y Cuervo \& Universidad Javeriana, 2012. 107-77.

y T. Morton. "Vernacular Spanish in a Microcosm: Kateyano." Revista Internacional de Lingüistica Iberoamericana 1 (2003): 97-159.

Storey, J. Teoría cultural y cultura popular. Barcelona: Octaedro, 2002.

Torres Valdez, José y Rosa Miranda Valdez. Primera conversación. Grabada y traducida por Yves Moñino. Archivo Moñino, 2002.

Trapero, M. "La poesía de tipo tradicional en Canarias". Historia Crítica de la Literatura Canaria, vol. I. Y. Arencibia y R. Fernández, eds. Las Palmas de Gran Canaria: 2000. 115-61.

Van Dijk, T. La ciencia del texto. Barcelona: Paidós, 1983.

$111 \frac{\text { Revista Iberoamericana, Vol. LXXXII, Núms. 255-256, Abril-Septiembre 2016, } 507-549}{\text { ISSN 2154-4794 (Electrónico) }}$ 
Vidal Ortega, A. Cartagena de Indias y la región. Histórica del Caribe, 1580-1640. Sevilla: Consejo Superior de Investigaciones Científicas / Universidad de Sevilla, 2012.

Weinrich, Harald. Estructura y función de los tiempos en el lenguaje. Madrid: Gredos, 1968. 
